Article

\title{
Effect of Vegetation on the Late Miocene Ocean Circulation
}

\section{Gerrit Lohmann ${ }^{1,2, *}$, Martin Butzin ${ }^{1,2}$ and Torsten Bickert ${ }^{2}$}

1 Alfred-Wegener-Institut Helmholtz Zentrum für Polar- und Meeresforschung, Bussestr. 24, 27570 Bremerhaven, Germany; E-Mail: Martin.Butzin@awi.de

2 MARUM, Center for Marine Environmental Sciences, University of Bremen, P.O. Box 330440, 28334 Bremen, Germany; E-Mail: tbickert@marum.de

* Author to whom correspondence should be addressed; E-Mail: Gerrit.Lohmann@awi.de; Tel.: +49-471-4831-1758.

Academic Editor: Nathalie Fagel

Received: 9 August 2015 / Accepted: 15 September 2015 / Published: 3 November 2015

\begin{abstract}
We examine the role of the vegetation cover and the associated hydrological cycle on the deep ocean circulation during the Late Miocene ( $\sim 10$ million years ago). In our simulations, an open Central American gateway and exchange with fresh Pacific waters leads to a weak and shallow thermohaline circulation in the North Atlantic Ocean which is consistent with most other modeling studies for this time period. Here, we estimate the effect of a changed vegetation cover on the ocean general circulation using atmospheric circulation model simulations for the late Miocene climate with 353 ppmv $\mathrm{CO}_{2}$ level. The Late Miocene land surface cover reduces the albedo, the net evaporation in the North Atlantic catchment is affected and the North Atlantic water becomes more saline leading to a more vigorous North Atlantic Deep Water circulation. These effects reveal potentially important feedbacks between the ocean circulation, the hydrological cycle and the land surface cover for Cenozoic climate evolution.
\end{abstract}

Keywords: ocean circulation; Late Miocene; hydrological cycle; Central American gateway 


\section{Introduction}

The Eocene-Oligocene and the Mid-Miocene climate transitions are two major cooling steps in the Cenozoic climate evolution (Zachos et al., 2001, [1]) from greenhouse to "icehouse" climate conditions. Ocean circulation changes and atmospheric $\mathrm{pCO}_{2}$ variations are often cited as potential catalysts of these cooling events (DeConto and Pollard, 2003, [2]). Tectonic reorganizations of gateways may have altered the large-scale ocean circulation, which in turn may have resulted in ice growth and global cooling (Kennett, 1977, [3]; Zachos et al., 2001, [1]). Carbon-13 proxy evidence (e.g., Wright and Miller, 1996, [4]; Billups, 2002, [5]) indicates pronounced ocean circulation changes in conjunction with the timing of tectonic events at critical ocean pathways like the Drake Passage, the Tasmanian Seaway, the Indonesian Seaway (Cane and Molnar, 2001, [6]; Lawver and Gahagan, 2003, [7]), the eastern Tethys (Flower and Kennett, 1994, [8]), and the Central American Seaway (e.g., Haug and Tiedemann, 1998, [9]). For a detailed review about the timing of the proxy records and their uncertainties, we refer to Mudelsee et al., (2014, [10]).

Here, we examine the climate for the early Late Miocene, i.e., the Tortonian (11-7 Ma, Ma: million years before present). The Tortonian is characterized by intensive Antarctic glaciation and the buildup of ice sheets in the North Atlantic realm. We focus on the spatial temperature distribution which is a principal problem in understanding Cenozoic climate change. In the case of the Miocene, elevated global-mean surface temperatures and weaker equator-to-pole temperature gradients are proposed (Greenwood and Wing, 1995, [11]; Crowley and Zachos, 2000, [12]; Pound et al., 2012, [13]). While numerical simulations exhibit rising global-mean temperatures for increasing greenhouse gas concentrations, they do not capture the reconstructed reduction in the meridional temperature gradient (Barron, 1987, [14]; Huber and Sloan, 2001, [15]; Micheels et al., 2011, [16]).

Some authors (Schmidt and Mysak, 1996, [17]; Hay et al., 1997, [18]; Micheels et al., 2011, [16]) have suggested that atmospheric heat transport may have played an important role in the temperature distribution. We would expect a warmer atmosphere to transport more latent heat toward the poles, helping to reduce meridional temperature gradients (polar amplification). However, despite the exponential increase of saturation vapor pressure with temperature, this water vapor feedback becomes less powerful as temperature rises (Caballero and Langen, 2005, [19]). Other possible mechanisms located in the atmosphere involve the atmospheric stationary wave response due to changing paleogeography and sea level.

On the other side, marine proxy data indicate that ocean gateway changes and major reorganizations of the global ocean circulation can play a crucial role for the climate evolution (e.g., Kennett, 1977, [3]; Wright et al., 1992, [20]; Zachos et al., 2001, [1]; Mudelsee et al., 2014, [10]). Concerning the Tortonian, the still open Central American Seaway (CAS, i.e., the Panama Strait) enabled the exchange of saline Atlantic water with comparatively fresher Pacific water (Montes et al., 2015, [21]), and it has been shown that this leads to a weakening of the thermohaline circulation in the North Atlantic Ocean (e.g., Mikolajewicz et al., 1993, [22]; Bice et al., 2000, [23]). Therefore, the Atlantic thermohaline circulation is unlikely to be responsible for a warmer climate at higher latitudes; at least in the Northern Hemisphere.

The question of temperatures might be linked to other feedbacks in the climate system, such as changes in the hydrological cycle and vegetation cover. Paleontological and palynological data give 
evidence for drastic changes in vegetation and therefore climate during the Cenozoic (Retallack, 2001, [24]; Willis and Mc Elwain, 2002, [25]). For example, during the Eocene/Oligocene glaciation ( $34 \mathrm{Ma})$, tropical rain forests virtually disappeared poleward of the northern and southern high-pressure zones (Retallack, 2001, [24]; Willis and Mc Elwain, 2002, [25]). Grasslands, which had begun to develop under dry conditions during the Eocene, covered larger areas in the Oligocene (after $\sim 34 \mathrm{Ma}$ ). During the Mid-Miocene Climatic Optimum ( $\sim 17$ to $15 \mathrm{Ma}$ ), moist, warm forests expanded poleward of the subtropical high-pressure zones for a short period (Retallack, 2001, [24]; Willis and Mc Elwain, 2002, [25]). Following the global climatic deterioration after the Mid-Miocene Climatic Optimum tropical rain forests withdrew again to the equatorial zone. Grasslands and deserts expanded through much of the lower mid-latitudes (Morley, 2000, [26]; Bredenkamp et al., 2002, [27]). C4-type grasslands became widespread during the interval from about 8 to $5 \mathrm{Ma}$ (Cerling et al., 1997, [28]; Freeman and Colarusso, 2001, [29]). During the Miocene most of the climatically arranged vegetation belts developed: ranging from rain forest along the equator to polar desert at high latitudes. However, to date, little is known about the connection between continental vegetation change and climate change during the Cenozoic. It is still an open question whether the vegetation adapted to hydrological changes or whether it played an active role as a modifier of major climate transitions. In principle, vegetation can contribute to a polar amplification through modifying the local albedo (e.g., Dutton and Baron, 1997, [30]; Otto-Bliesner and Upchurch, 1997, [31]). In the light of these findings we investigate whether such a feedback could have been effective during the Late Miocene. In particular, we are interested in the sensitivity of the Miocene ocean circulation with respect to the vegetation cover and associated hydrological cycle in conjunction with the open Central American gateway.

\section{Methods}

In order to evaluate the Miocene land surface cover and its associated hydrological cycle, we use the output of an atmospheric circulation model under different assumptions for the land cover parameters to force a dynamical vegetation model and an ocean circulation model.

\subsection{Atmospheric Circulation Model}

For the Late Miocene climate simulations, we apply the atmosphere general circulation model ECHAM4 (Roeckner et al., 1996, [32]). The prognostic variables are calculated in the spectral domain with a triangular truncation at wave number 30 (T30), which corresponds to a Gaussian longitude-latitude grid of approximately $3.75^{\circ}$. The vertical domain is represented by 19 hybrid sigma-pressure (terrain following) levels with the highest level at $10 \mathrm{hPa}$. The model is coupled to a $50 \mathrm{~m}$ slab ocean. This allows a prescription of the Miocene ocean heat transport consistent with proxy data (Steppuhn et al., 2006, [33]). Furthermore, the orography is adapted to the Tortonian when the height of mountain ranges was generally reduced (references in Steppuhn et al., 2006, [33]). For example, Greenland reaches only about a tenth of its recent elevation. In addition to the aforementioned boundary conditions, the atmospheric $\mathrm{CO} 2$ is prescribed with the present-day level of $353 \mathrm{ppmv}$ for all experiments. This value ranges in the spectrum commonly used for the Miocene (Freeman and Hayes, 1992, [34]; Cerling et al., 1997, [28]; Pagani et al., 1999, [35]; Pearson and Palmer, 2000, [36]; Demicco et al., 2003, [37]; Pagani et al., 2005, [38]; Kürschner et al., 2008, [39]; Zhang et al., 2013, [40]). 
For the land surface, sensitivity experiments were performed which are described below. Each model simulation with the atmospheric general circulation model (AGCM) was run over 20 years. The model reaches an equilibrium state after 5 years, and the last 10 years are taken into account for further analysis. Vegetation is a fixed factor represented through the specification of different land surface parameters like albedo, roughness length, vegetation ratio, leaf area index and maximum soil water capacity. This model approach has been applied and validated with proxy data in an investigation of heat transport mechanisms for the Late Miocene (Micheels et al., 2011, [16]) and warm climate during the Late Miocene (Knorr et al., 2011, [41]). Depending on the surface and vegetation type, physical quantities like the background albedo or roughness length are changed and prescribed. The albedo is a function of the background albedo, and on climate variables like snow depth and ice (Roeckner et al., 1996, [32]).

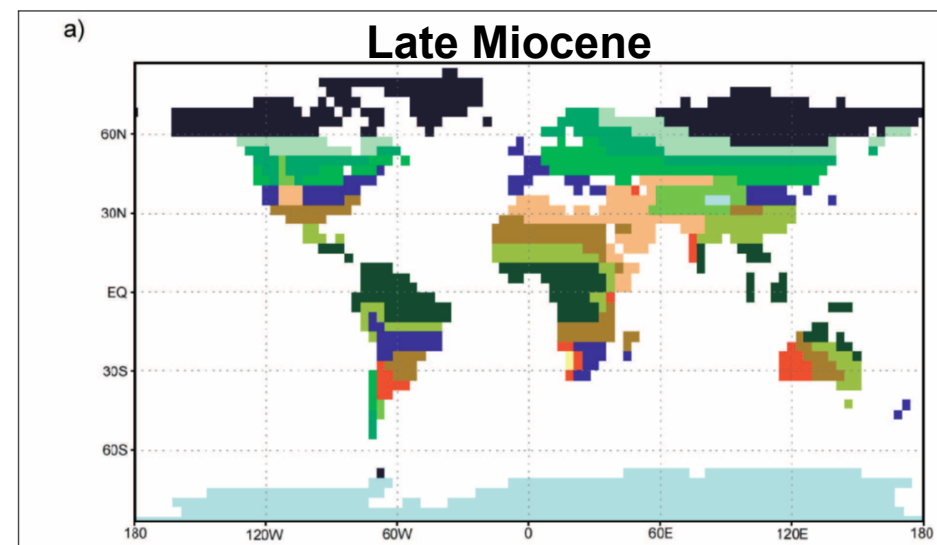

b)

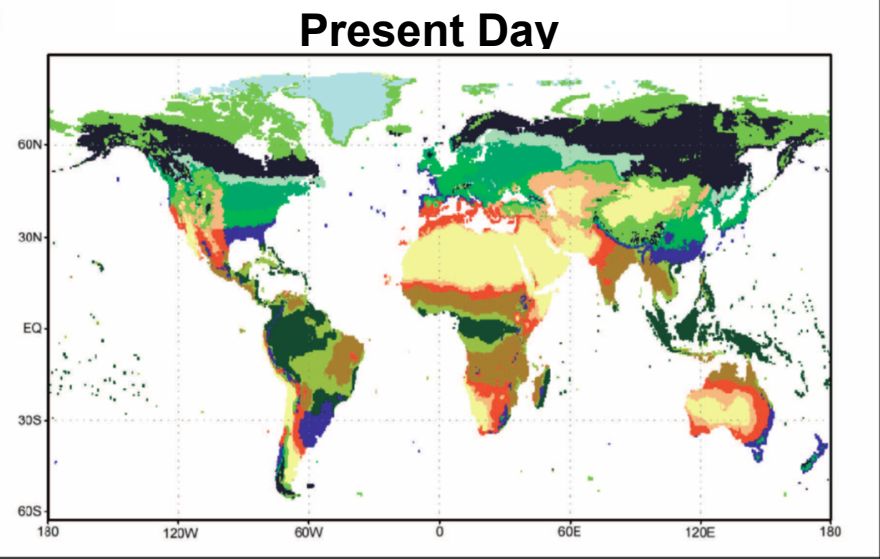

$\square$ tropical rain forest

tropical seasonal forest

savanna

warm mixed forest

temperate deciduous forest

cool \& cold mixed forest

cool conifer forest

taiga \& cold deciduous forest

xerophytic woods

warm grass

cool grass \& tundra

hot, cool \& sand desert

polar desert

Figure 1. (a) The proxy-based reconstructed Tortonian vegetation; and (b) the present-day's vegetation (New et al., 1999) [42]. These maps serve as an input into the atmospheric general circulation model (AGCM) experiments TVEG (a), TGEO (b) and CTRL (b). Warm grass corresponds to subdesertic Mediterranean-like open vegetation.

Based on the Late Miocene boundary conditions described above, we performed two Tortonian sensitivity experiments with respect to the vegetation. The first Tortonian simulation (TGEO) used the present-day vegetation, except that Greenland glaciers were replaced by tundra vegetation (Steppuhn et al., 2006, [33]). The second Tortonian run (TVEG) uses a proxy-based reconstruction of the palaeovegetation (Figure 1) (Micheels, 2003, [43]; Micheels et al., 2007, [44]). The palaeovegetation 
represents a generally larger forest cover than today and forest margins shift farther poleward. Grasslands and deserts/semi-deserts are reduced in the Late Miocene. For example, in North Africa the Late Miocene vegetation reconstruction shows warm grassland to savanna vegetation without any desert area. It is an on-going debate whether North Africa was humid until the Pliocene (e.g., Pickford, 2000, [45]; Micheels et al., 2009, [46]) or whether the Sahara desert first appeared at the end of the Miocene ( 7 to $6 \mathrm{Ma}$ ) (e.g., Vignaud et al., 2002, [47]; Schuster et al., 2006, [20]). For the Tortonian (11 to $7 \mathrm{Ma}$ ), a non-desert situation in North Africa as an intermediate state in between the Early Miocene tropical forests (Wolfe, 1985, [48]; Dutton and Barron, 1997, [8]) and desert in the Pliocene (e.g., Schuster et al., 2006, [20]) is consistent with the fossil record. For TVEG, land surface parameters (albedo, leaf area index, vegetation and forest cover, and maximum soil water capacity) are changed for each grid point. A list of the experiments is given in Table 1.

Table 1. List of experiments.

\begin{tabular}{|c|c|c|c|}
\hline & CTRL & TGEO & TVEG \\
\hline \multicolumn{4}{|c|}{ Atmosphere: ECHAM4 } \\
\hline SST & modern & Steppuhn et al., (2006), [33] & Steppuhn et al., (2006), [33] \\
\hline ocean heat transport & modern & Steppuhn et al., (2006), [33] & Steppuhn et al., (2006), [33] \\
\hline $\mathrm{CO}_{2}$ & 353 ppmv & 353 ppmv & 353 ppmv \\
\hline land & modern & Greenland/Tibet & Greenland/Tibet \\
\hline vegetation & modern & modern & Micheels et al., (2007), [36] \\
\hline \multicolumn{4}{|c|}{ Ocean: LSG } \\
\hline ocean gateways & modern & CAS $500 \mathrm{~m}$ & CAS $500 \mathrm{~m}$ \\
\hline wind and hydrological cycle & from CTRL & from TGEO & from TVEG \\
\hline salinity and temperature & calculated & calculated & calculated \\
\hline \multicolumn{4}{|c|}{ Vegetation: LPJ } \\
\hline vegetation & calculated & - & calculated \\
\hline
\end{tabular}

\subsection{Dynamical Vegetation Model}

The Lund-Potsdam-Jena dynamical vegetation model LPJ (Sitch et al., 2003, [49]) combines process-based descriptions of terrestrial ecosystem structure (vegetation composition, biomass and height) and function (energy absorption, carbon cycling). Vegetation composition is described by nine different plant functional types (PFTs), which are distinguished according to their physiological ( $\mathrm{C}_{3-}, \mathrm{C}_{4}$-type photosynthesis), morphological (tree, grass) and phenological (deciduous, evergreen) attributes. The model is run on a horizontal $2^{\circ} \times 2^{\circ}$ grid, directly forced with the output of the AGCM experiments. The model is run on a grid cell basis with input of soil texture, monthly fields of temperature, precipitation, short- and long-wave radiation. The soil texture is taken from present values. Each grid cell is divided into fractions covered by the PFTs and bare ground. Both the presence and the covered fraction of PFTs within a grid cell depend on their specific environmental limits and on resource competition among the PFTs. Carbon isotope fractionation is included in the model (Kaplan et al., 2002, [50]; Scholze et al., 2003, [51]). 


\subsection{Ocean Circulation Model}

Our ocean model is an updated version of the LSG circulation model developed by Maier-Reimer et al., (1993, [52]). We implemented some significant improvements such as a new advection scheme for tracers (Schäfer-Neth and Paul, 2001, [53]; Prange et al., 2002, [54]; Prange et al., 2003, [55]) and an overflow parameterization for the bottom boundary layer (Lohmann, 1998, [56]; Lohmann and Schulz, 2000, [57]). The spatial resolution is $3.5^{\circ} \times 3.5^{\circ}$ in the horizontal and 22 levels in the vertical. We calibrated the model by simulating anthropogenic carbon-14 (Butzin et al., 2005, [58]). The ocean is forced by 10-year averaged monthly fields of wind stress, surface air temperature, and freshwater flux (precipitation-evaporation), which serve as background climatology and originate from the simulations with the AGCM ECHAM4 described in Section 2.1.

In the ocean circulation experiments, we employ a hybrid coupled modeling approach, which allows an adjustment of surface temperatures and salinity to changes in the ocean circulation, based on an atmospheric energy balance model (Lohmann and Gerdes, 1998, [59]; Prange et al., 2003, [55]). No flux correction is applied for present day and other climate conditions. This approach permits that sea surface temperatures (SST) can freely adjust to ocean circulation changes (e.g., see Prange et al., 2003, [55]; Knorr and Lohmann, 2003, [60]; Butzin et al., 2005, [58]). The hydrological cycle is closed by a runoff scheme that considers continental catchment areas and allows for variable land-sea distributions, which permits that sea surface salinities (SSS) can freely evolve. The total integration time of each experiment is 5000 years. For the late Miocene simulations, we assumed a $500 \mathrm{~m}$ deep and three gridpoints wide (between $9^{\circ} \mathrm{N}$ and $18^{\circ} \mathrm{N}$ ) gateway between the Atlantic and Pacific Oceans.

\section{Results}

\subsection{Albedo, Hydrological Cycle and Vegetation Cover}

In order to check the consistency of the reconstructed vegetation distribution with the modeled climate in TVEG, we apply the dynamical vegetation model LPJ. We use the monthly output of the last 10 years of the CTRL and TVEG simulations, iterating these simulations 200 times to achieve an equilibrium of the dynamical vegetation model after 2000 model years. We build an average over the last 500 years and identify the spatial patterns of the PFTs for the Tortonian and present-day vegetation cover (Figure 2). For the late Miocene, simulated tropical trees are spread into subtropical Africa (North and South) and parts of Australia, whereas temperate trees are extended over Asia relative to present conditions. The extension of boreal forests far into the northern high latitudes during the Tortonian is in accordance with proxy data (Boulter and Manum, 1997, [61]). Grassland is extended into subtropical areas, over Greenland and over Alaska. The Sahara desert is smaller than today and consists of steppes and open grassland rather than sand desert which is consistent with fossil data (Schuster et al., 2006, [62]; Micheels et al., 2009, [46]).

When comparing TVEG with CTRL and TGEO, altering the land surface parameters to that appropriate for the Late Miocene causes the surface albedo to decrease for most regions on the globe (Figure 3). The strongest changes are found over northern Asia and North America, and over North Africa. The removal of inland ice on Greenland causes surface temperatures to rise and the associated reduction in the ice-albedo feedback mechanism reduces sea ice in the northern high latitudes. 

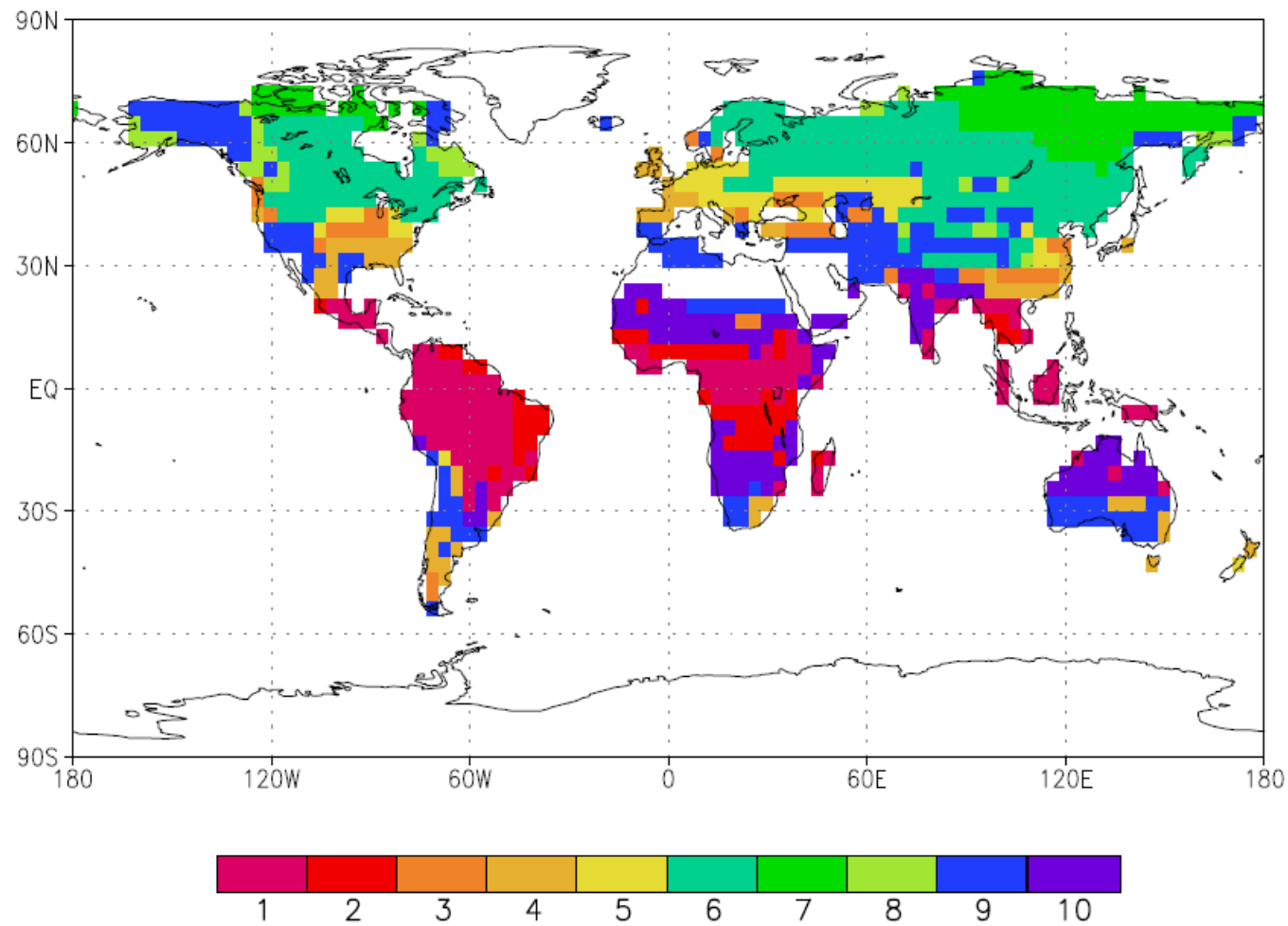

$1=$ tropical broadleaved evergreen tree

2 = tropical broadleaved raingreen tree

$3=$ temperate needleleaved evergreen tree

$4=$ temperate broadleaved evergreen tree

5 - temperate broadleaved summergreen tree
6 = boreal needleleaved evergreen tree

$7=$ boreal needleleaved summergreen tree

$8=$ boreal broadleaved summergreen tree

$9=\mathrm{C} 3$ perennial grass

10 - C4 perennial grass

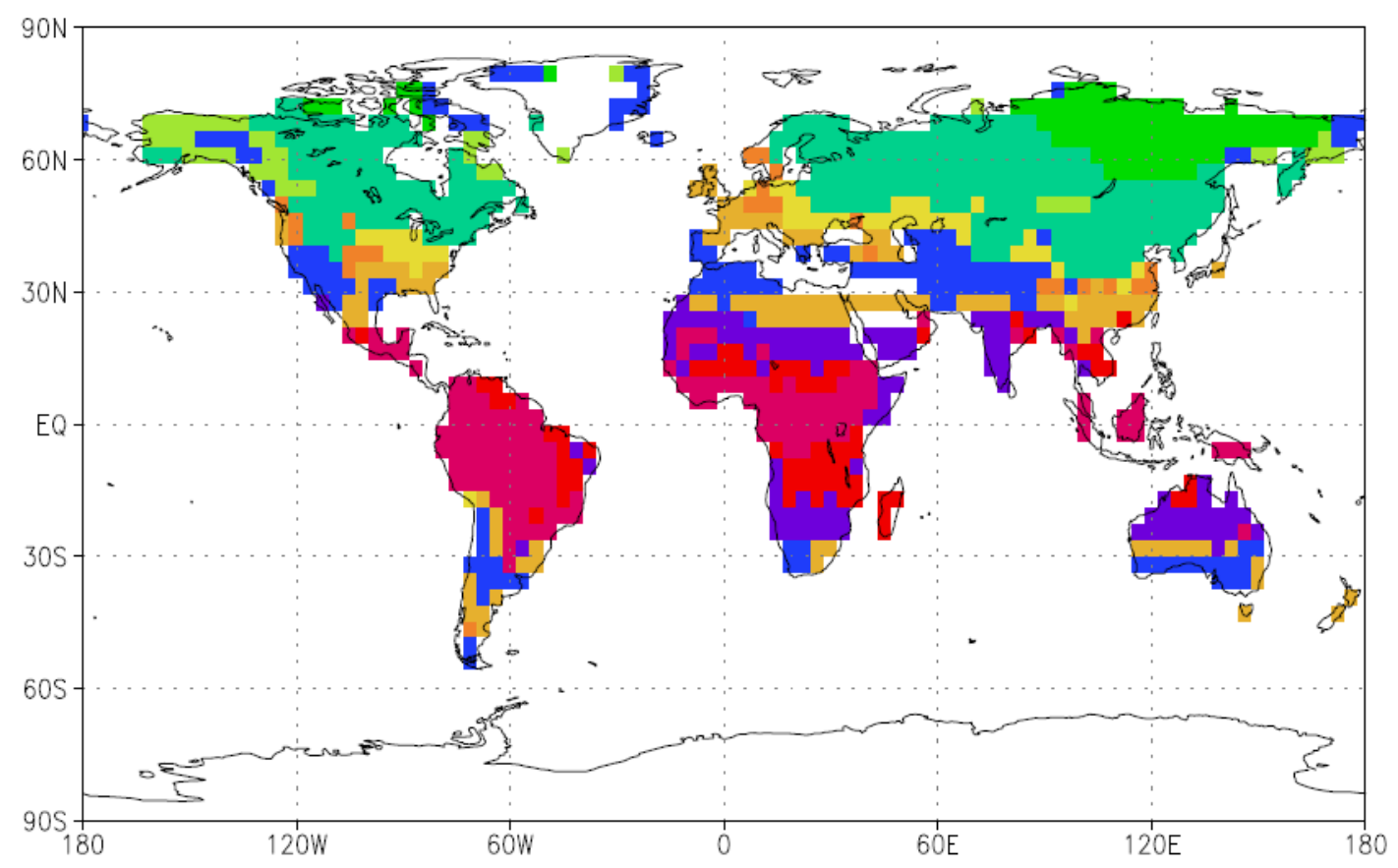

Figure 2. Dominant plant functional types as simulated by the LPJ dynamical vegetation model for present (upper panel) and Tortonian conditions (lower panel). The model has been run to equilibrium conditions (see text for details). White areas indicate regions with no vegetation. 
a)

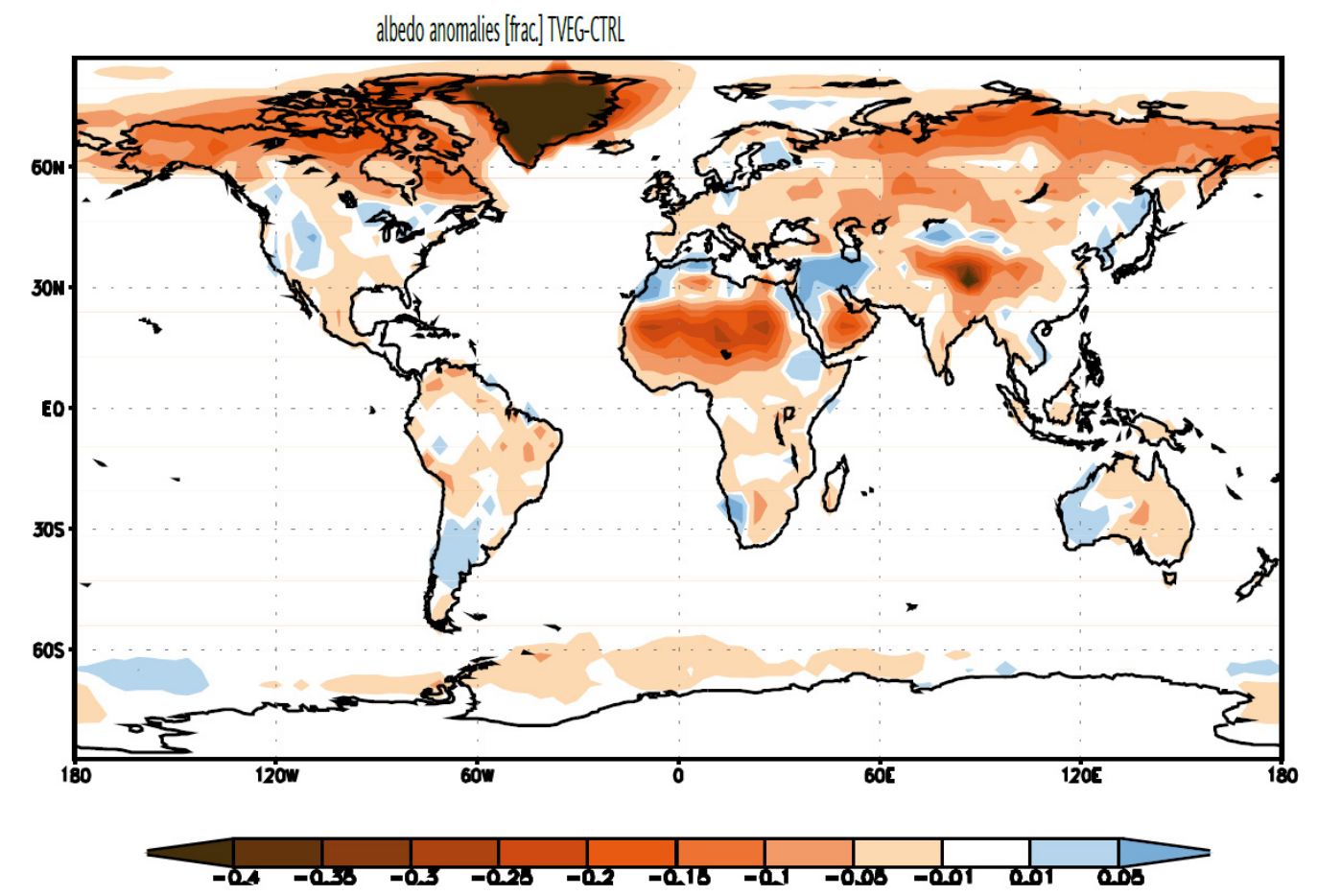

b)

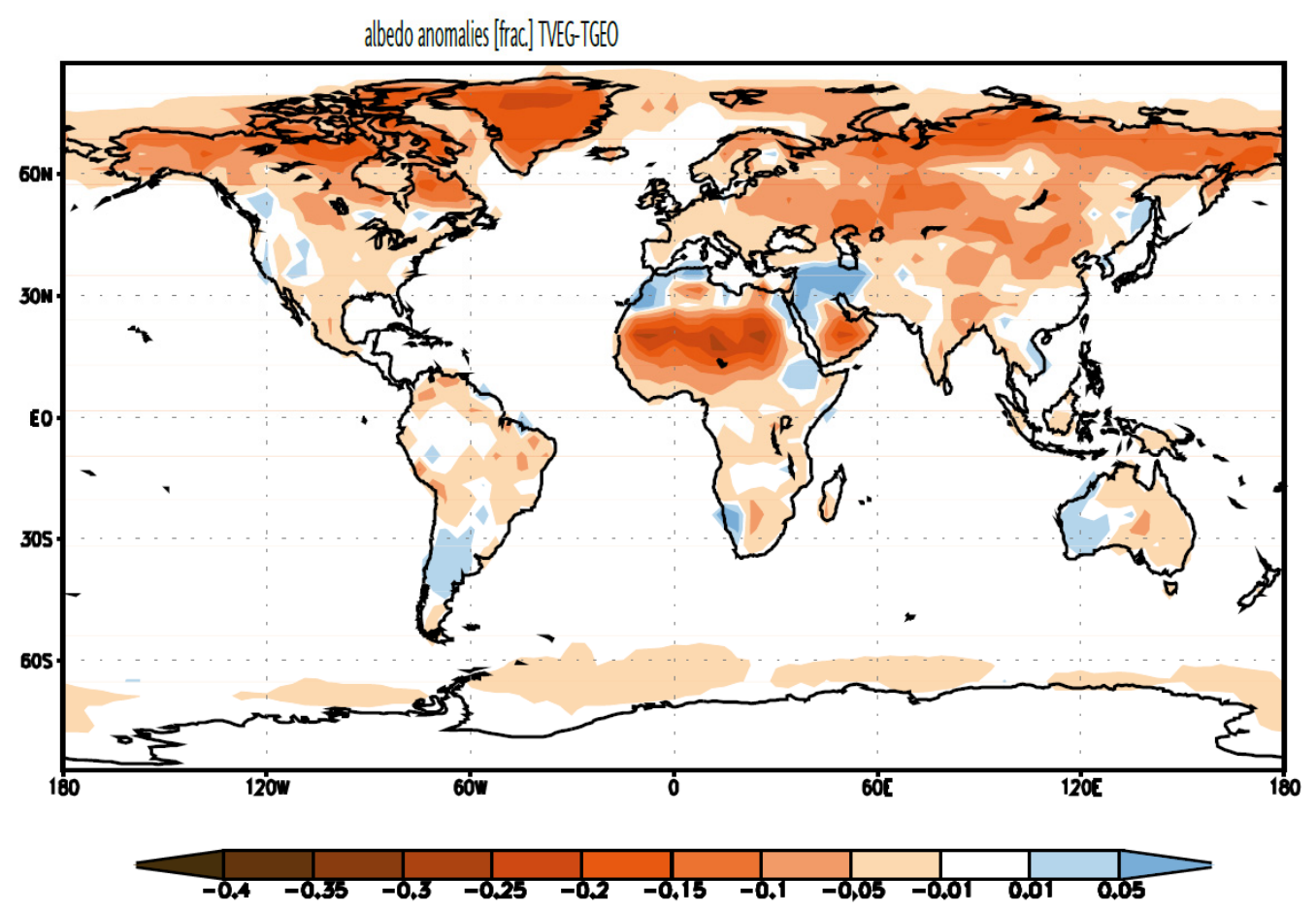

Figure 3. Changes in the mean annual albedo (frac.) for (a) TVEG minus CTRL; and for (b) TVEG minus TGEO.

Figure 4 shows the zonally integrated freshwater flux over the Atlantic catchment area (cf., Lohmann, 2003, [63]). In the subtropics there is considerably more net evaporation for TVEG than for CTRL and TGEO. The integrated net evaporation between $10^{\circ}$ and $50^{\circ} \mathrm{N}$ is $0.227 \mathrm{~Sv}$ (CTRL), 0.209 $\mathrm{Sv}$ (TGEO), $0.305 \mathrm{~Sv}$ (TVEG), respectively. (The unit $1 \mathrm{~Sv}$ corresponds to a mass transport of $10^{9} \mathrm{~kg} \mathrm{~s}^{-1}$, equivalent to a volume transport of $10^{6} \mathrm{~m}^{3} \mathrm{~s}^{-1}$ of liquid water.) Maximum transport is found for TVEG, which is linked to zonal winds and a water vapor export out of the Atlantic catchment area. The wind anomalies 
between TVEG and TGEO are shown in Figure 5. The wind anomalies are largely related to changes in surface temperature. Pronounced changes are seen over North Africa with enhanced monsoonal circulation in the boreal summer (Figure 5b). The zonal circulation towards the African continent and the Indian Ocean is enhanced in TVEG, associated with increased land-sea contrast between $2{ }^{\circ} \mathrm{C}$ and $6{ }^{\circ} \mathrm{C}$ and increased precipitation over the Sahel region and the Indian Ocean. In a sensitivity study, Micheels et al., $\left(2009\right.$, [46]) found that the Sahara region greening leads to a temperature rise of up to $6{ }^{\circ} \mathrm{C}$ and a significant increase in precipitation in the Sahel region and the Indian region (cf. Figure 2, Micheels et al., 2009, [46]). The pronounced clockwise circulation over a center at $60^{\circ} \mathrm{W}, 30^{\circ} \mathrm{N}$ (Figure 5b) is most likely linked to the barotropic response to a relative cooling in this area. This circulation indicates an increased transport out of the Atlantic basin, especially during the boreal summer season when the moisture transport is maximal. Furthermore, we detect a strong change in the North Pacific Ocean which reaches its maximum in boreal winter (Figure 5a). A pronounced change can also be detected for the annual mean circulation (Figure 5c).

For the momentum flux it is interesting to note that the zonal wind stress in the Atlantic Ocean is only slightly affected for TVEG and lies between the CTRL and TGEO simulations (Figure 6). The meridional wind stress (Figure 7) is similar in the experiments TVEG and TGEO, except for a region around $50^{\circ} \mathrm{N}$.

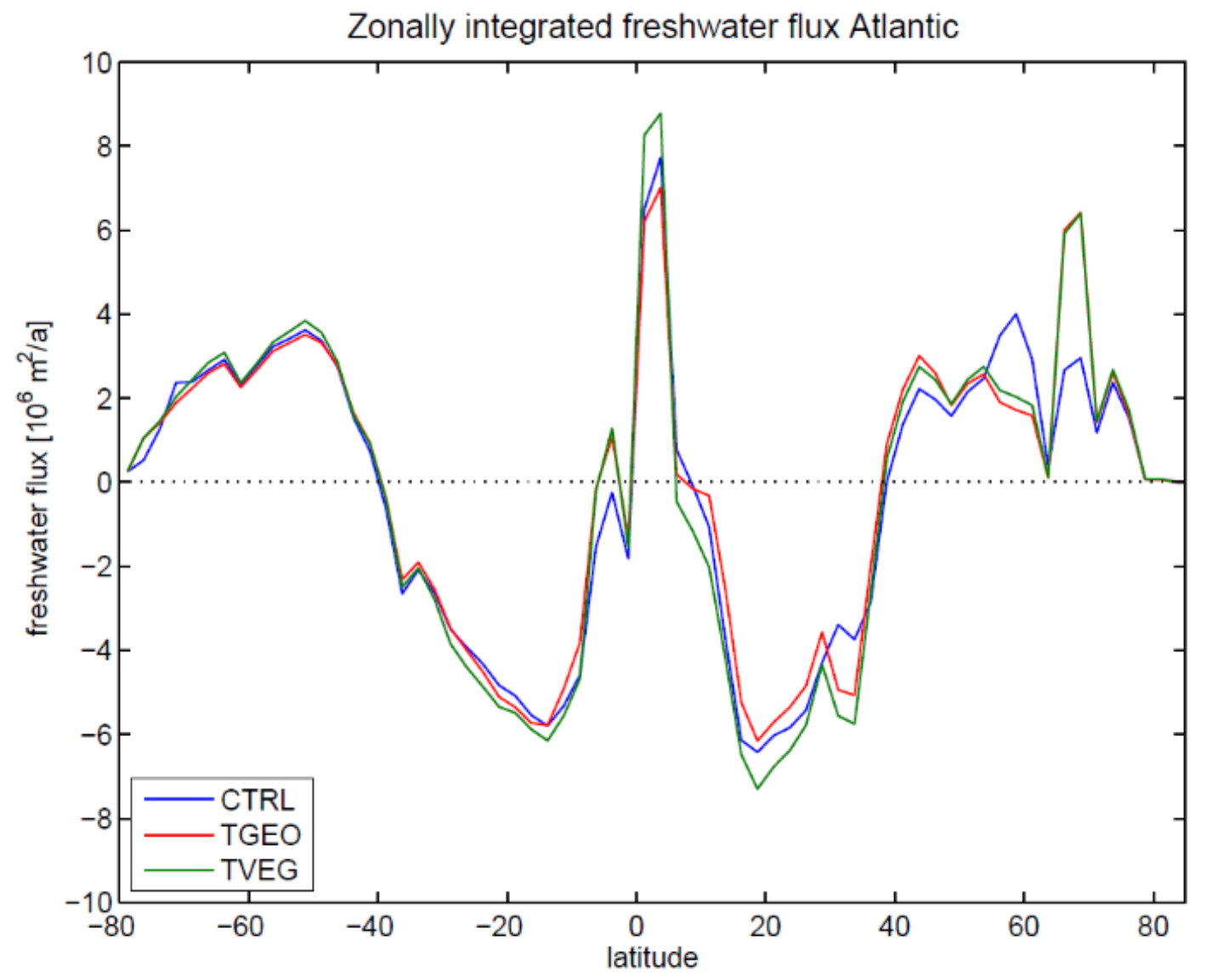

Figure 4. Annual mean net freshwater fluxes in the Atlantic Ocean for CTRL, TGEO, and TVEG. For the calculation of the net freshwater flux, the catchment areas in the ocean model have been taken into account (as in Lohmann, 2003, [63]). South of $35^{\circ} \mathrm{S}$, the Atlantic Ocean is defined by the longitudes of the southern tips of South America and Africa, respectively. 


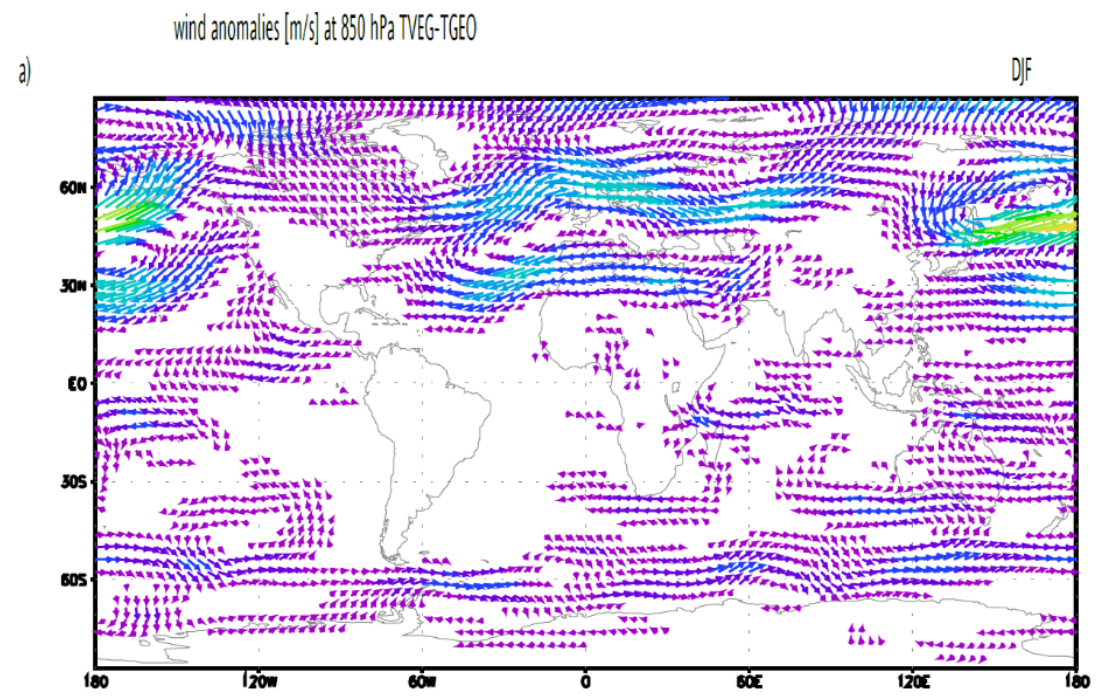

b)

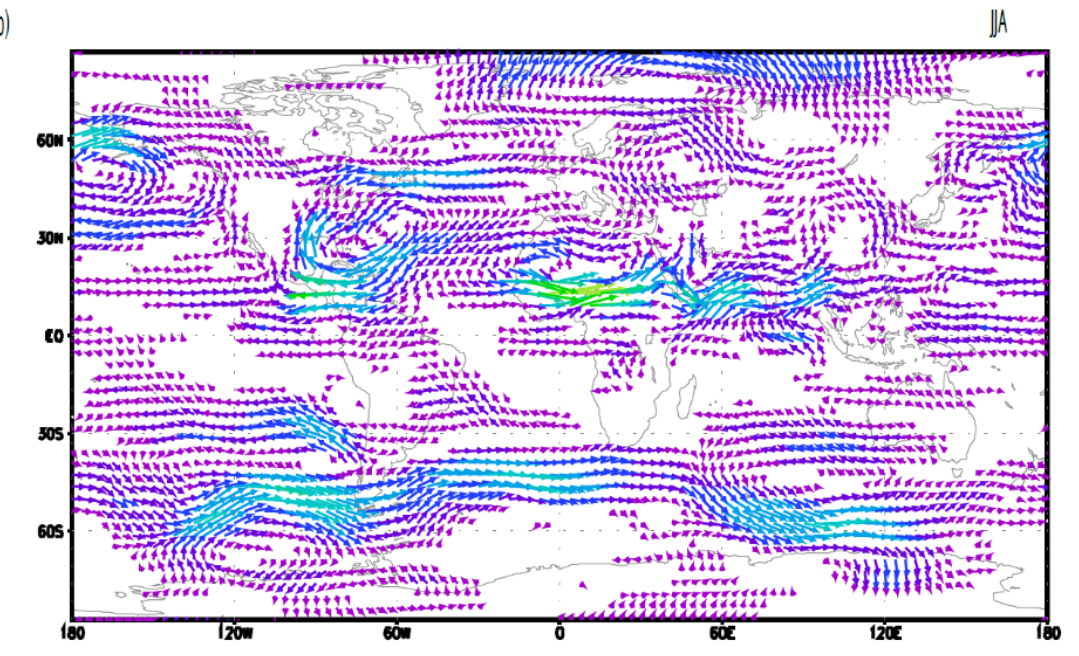

c)

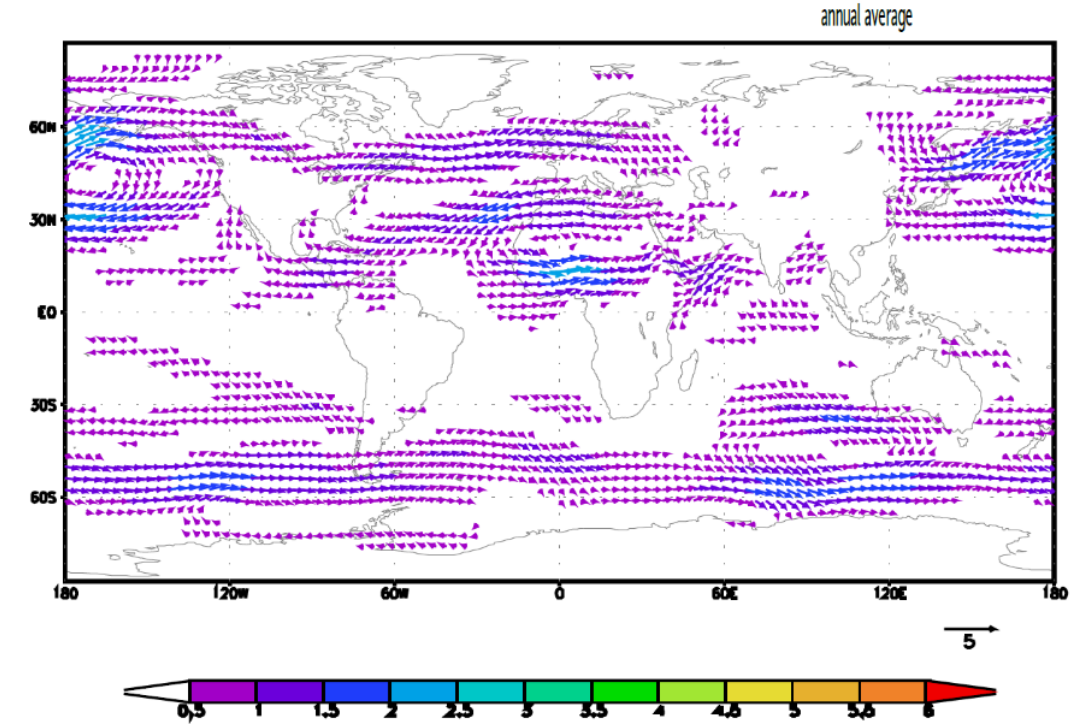

Figure 5. Changes in the wind field $(\mathrm{m} / \mathrm{s})$ at $850 \mathrm{hPa}$ for TVEG minus TGEO. (a) Boreal winter: December-January-February; (b) boreal summer: June-July-August; (c) annual mean. The reference arrow represents $5 \mathrm{~m} / \mathrm{s}$. Vectors for differences of less than $0.5 \mathrm{~m} / \mathrm{s}$ are not shown. 


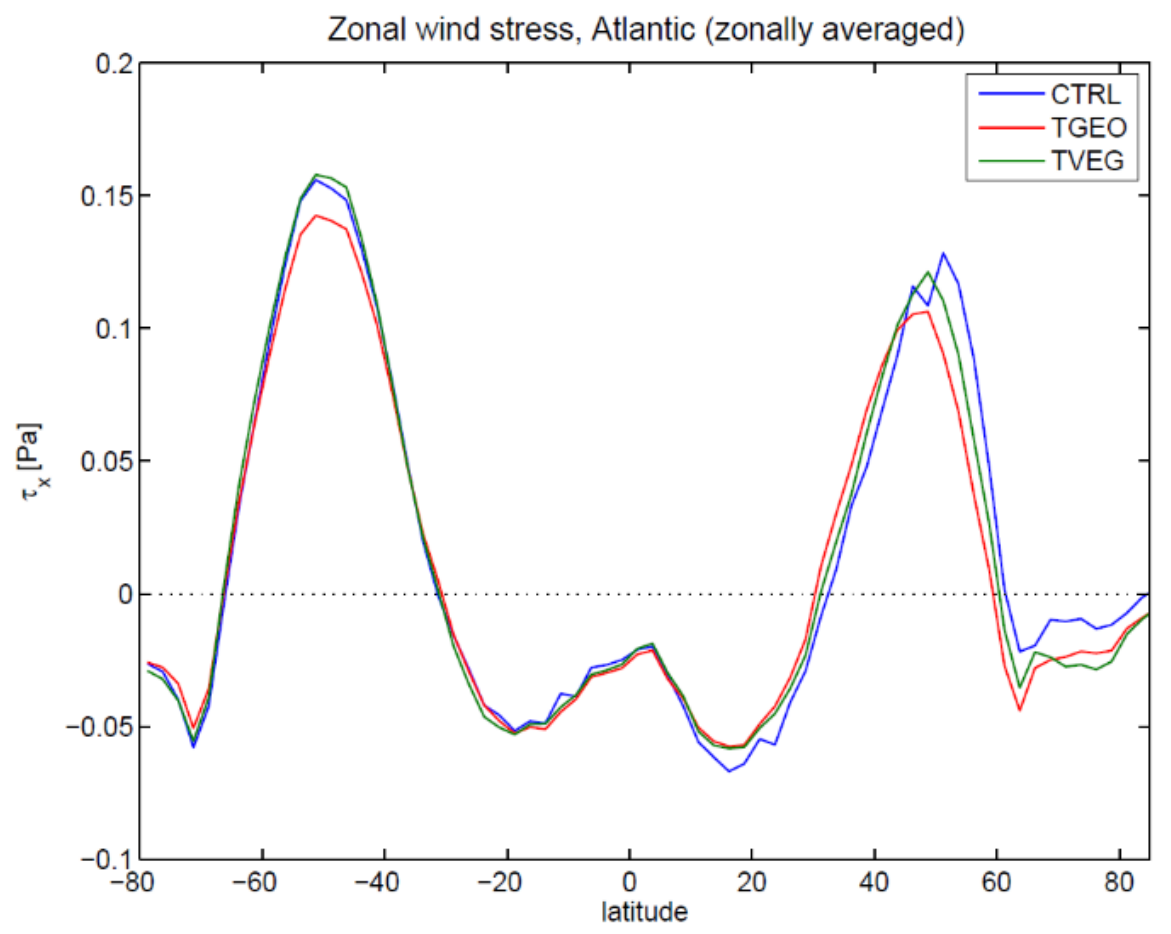

Figure 6. Zonal mean zonal wind stress in the Atlantic Ocean for CTRL, TGEO, and TVEG.

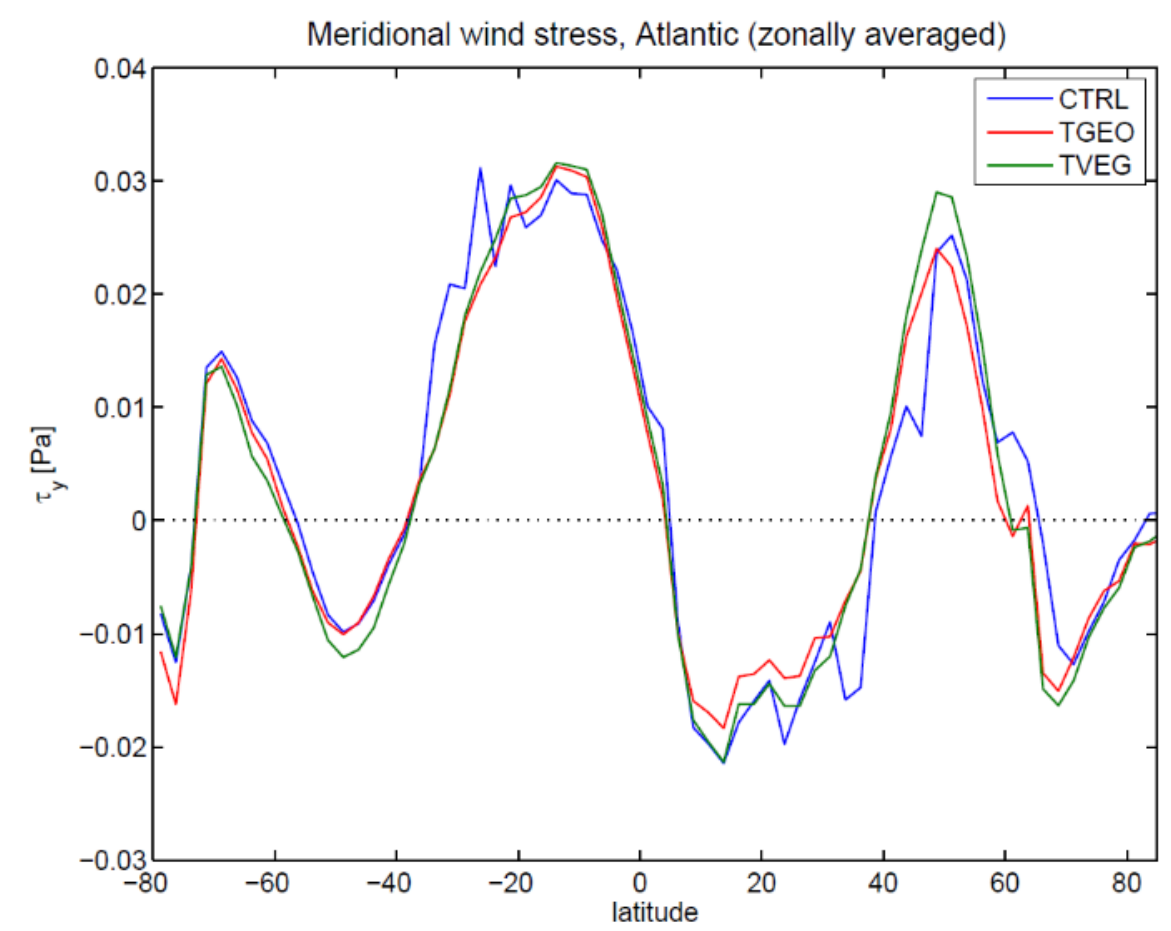

Figure 7. Same as Figure 6, but for the meridional wind stress.

\subsection{Ocean Circulation}

The control experiment for present-day conditions (Figure 8a) reasonably reflects the modern Atlantic Ocean circulation with a southward water export of $16 \mathrm{~Sv}$ at $30^{\circ} \mathrm{S}$ and a heat transport of $0.96 \mathrm{PW}$ $\left(1 \mathrm{PW}=10^{15} \mathrm{~W}\right)$ at $30^{\circ} \mathrm{N}$, which is in the range of oceanographic observations (Schmitz, 1995, [64]; 
Macdonald and Wunsch, 1996, [65]). A comparison of the control run with the Tortonian experiments (TGEO, TVEG) reveals significant changes in the meridional overturning circulation (Figure 8b,c): The formation of deep water in the North Atlantic is strongly reduced (TGEO) when the Central American Seaway (CAS) is open (Figure 8). The meridional circulation is only $3 \mathrm{~Sv}$ and represents a "mini-conveyor belt" circulation with an ocean heat transport at $30^{\circ} \mathrm{N}$ of $0.19 \mathrm{PW}$ (Figure 8b). In experiment TVEG, the circulation strength is similar to present-day conditions (14 Sv export at $30^{\circ} \mathrm{S}$, $0.83 \mathrm{PW}$ at $30^{\circ} \mathrm{N}$ ), but slightly shallower than today. The reason might be the increased flow of bottom water from the Antarctic (Figure 8c).

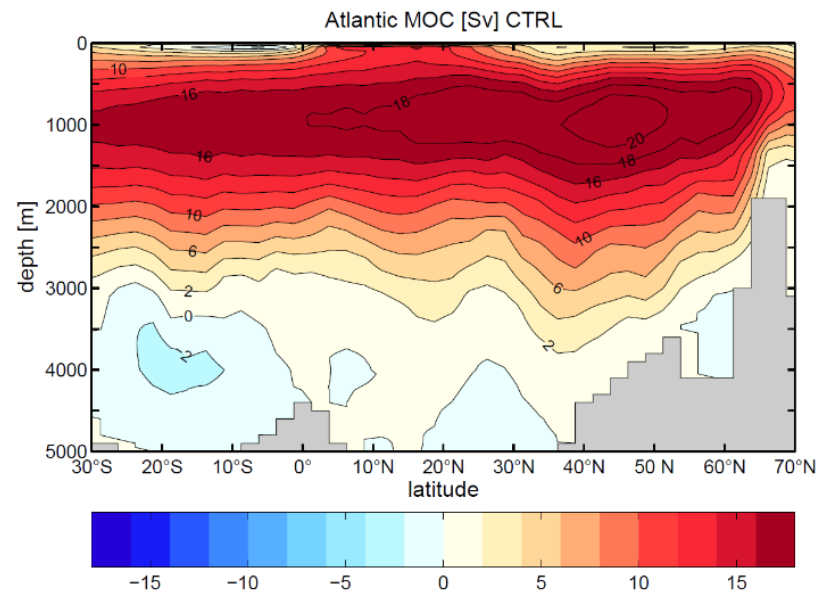

(a)

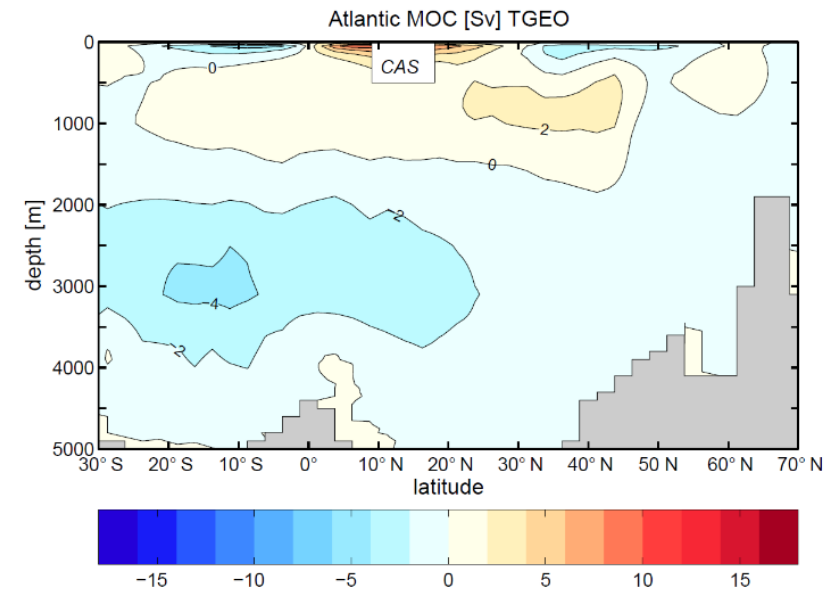

(b)

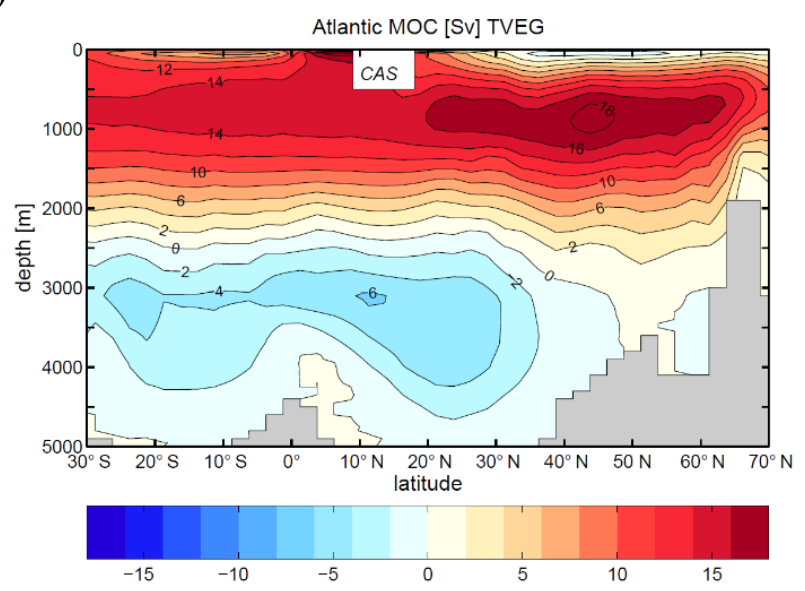

(c)

Figure 8. Atlantic meridional overturning circulation $\left(\mathrm{Sv}=10^{6} \mathrm{~m}^{3} / \mathrm{s}\right)$ for present-day (a), and the late Miocene configuration with open Central American Seaway (CAS); (b) with present vegetation cover (TGEO); and (c) with reconstructed vegetation cover (TVEG). Note that the Atlantic meridional overturning stream function is only defined if the ocean basin is bounded either side by land. We calculate the stream function from the bottom of the ocean to the top. Therefore, the open seaway is blanked out in the panels b and c.

A detailed analysis of the flow patterns in various depths of the CAS shows an export of surface water from the Atlantic to the Pacific Ocean (Figure 9a). The import of thermocline and intermediate layer water from the Pacific to the Atlantic Ocean is responsible for a reversal of the Northeast Brazil Current (Figure 9a). The subsurface transport for depths of more than $200 \mathrm{~m}$ is $27 \mathrm{~Sv}$ and $29 \mathrm{~Sv}$ for TGEO and 
TVEG, respectively. The net flux of Pacific water through the CAS into the Atlantic leads to thermocline water of relative low salinity. This freshening inhibits deep-water formation in the North Atlantic. In TGEO, the surface winds and atmosphere-ocean net freshwater flux in the North Atlantic are not able to overcome this freshening by the open CAS (Figure 8b). In contrast to TVEG, a stronger northward flow (Figure $9 \mathrm{~b}$ ) and increase in net evaporation are sufficient to push the ocean circulation into a present-day-like circulation mode (Figure 8c). Both the increased ocean circulation with a northward shift of the Arctic sea ice, and a local warming associated to the land surface quantities, induce an anomalous warming between TVEG and TGEO of up to $8{ }^{\circ} \mathrm{C}$ (Figure $9 \mathrm{~b}$ ). Note that all experiments were carried out for $\mathrm{pCO}_{2}=353 \mathrm{ppmv}$. Figure 10a displays the zonal mean sea-surface temperature in the Atlantic Ocean. North of $30^{\circ} \mathrm{S}$, the surface temperature in TVEG is increased compared to CTRL and TGEO in the zonal mean. Interestingly, the strongest temperature change between TVEG and CTRL (more than $3{ }^{\circ} \mathrm{C}$ ) is in the subsurface of the Atlantic Ocean (Figure 10b). This increase is strongest between $40^{\circ} \mathrm{S}$ and $20^{\circ} \mathrm{N}$ at $500 \mathrm{~m}$ depth. Pronounced warming is detected for a region around Iceland and in the northern North Pacific (Figure 9a).

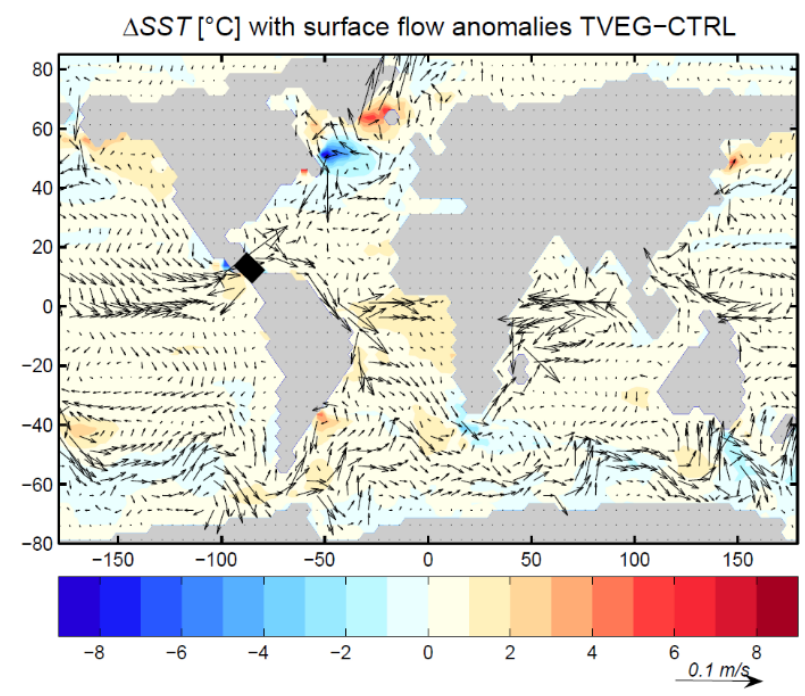

(a)

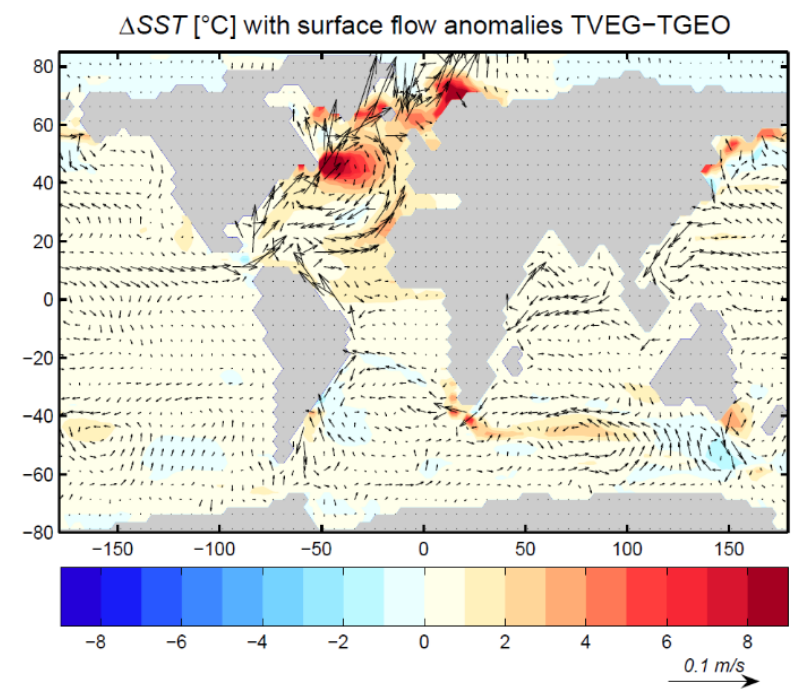

(b)

Figure 9. Modeled sea surface temperature anomalies $\left[{ }^{\circ} \mathrm{C}\right]$ and surface flow $[\mathrm{m} / \mathrm{s}]$. (a) Difference between TVEG and CTRL; (b) difference between TVEG and TGEO.

In TGEO, the drop in meridional ocean circulation is accompanied by a reduction in sea surface salinity in the North Atlantic (Figure 11a). Due to the exchange of surface water in the CAS, the surface water in the tropical Pacific becomes more saline. In contrast to TGEO, the stronger ocean circulation for TVEG is related to the considerably higher sea surface salinities in the North Atlantic Ocean (Figure 11b). The increased water vapor transport (as seen in the increase in $850 \mathrm{hPa}$ winds) provides a source for net negative freshwater flux in the North Atlantic basin (a net evaporation anomaly) affecting sea surface salinity. The strong increase in North Atlantic upper $500 \mathrm{~m}$ salinity is clearly emphasized in the Atlantic zonal-mean salinity distribution (Figure 12a). The surface and subsurface warming of TVEG relative to TGEO is strongest in the subtropics and polar latitudes (Figure 12b). At northern polar latitudes, the warming is associated to strong poleward surface currents (Figure 10b), sea ice retreat, and meridional heat transport. 


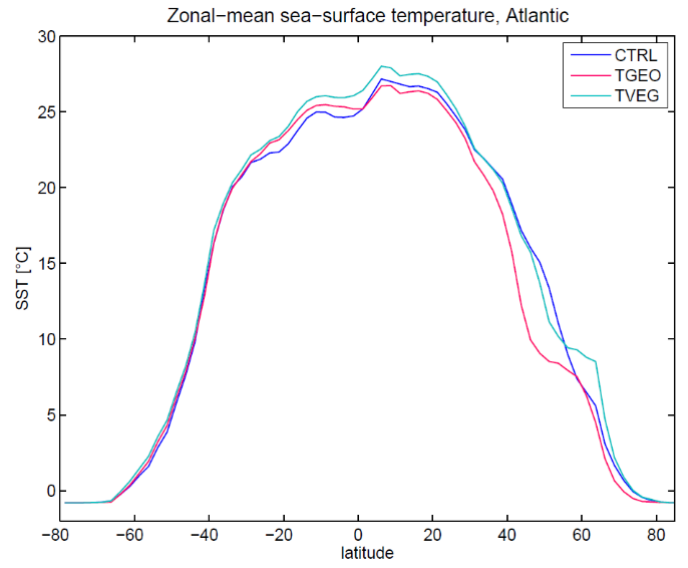

(a)

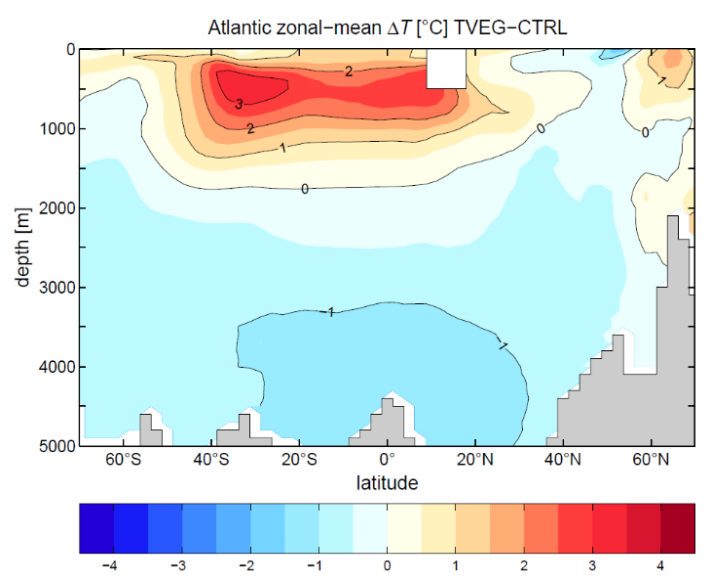

(b)

Figure 10. (a) Zonal mean sea surface temperature $\left[{ }^{\circ} \mathrm{C}\right]$ for $\mathrm{CTRL}$, TGEO, and TVEG; (b) zonal mean Atlantic temperature anomaly TVEG-CTRL $\left[{ }^{\circ} \mathrm{C}\right]$.

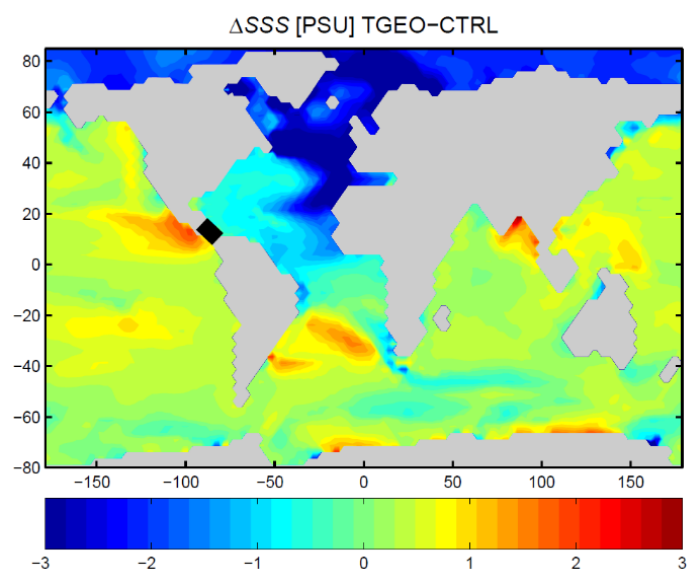

(a)

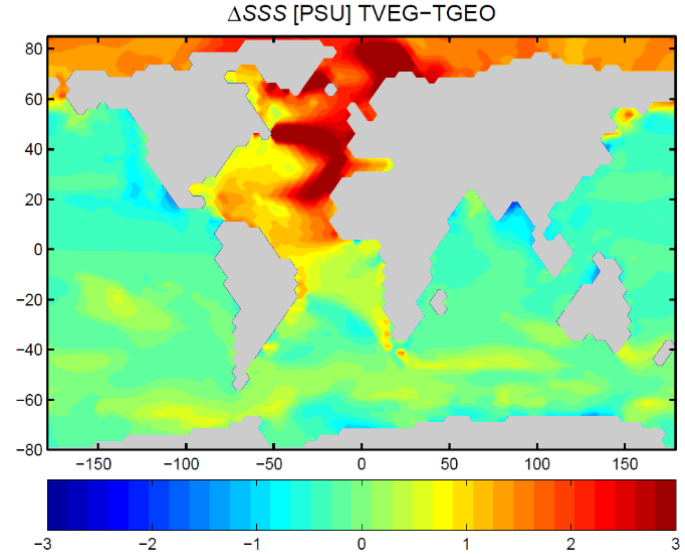

(b)

Figure 11. Modeled sea surface salinity anomalies [PSU]. (a) Difference between TGEO and CTRL; (b) difference between TVEG and TGEO.

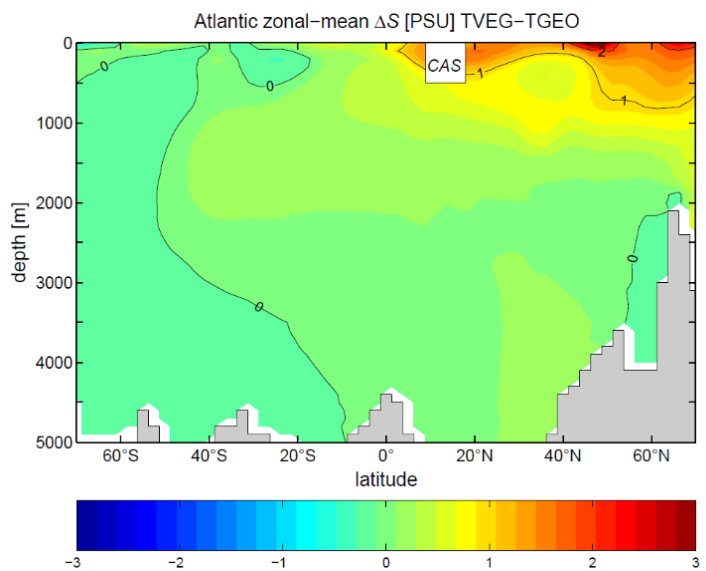

(a)

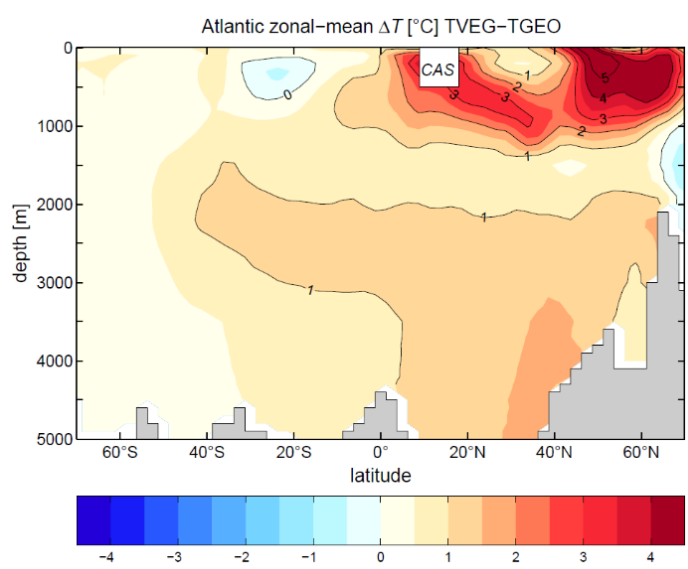

(b)

Figure 12. Zonal mean difference between TVEG and TGEO in the Atlantic Ocean: (a) salinity; (b) temperature. 


\section{Discussion}

We have evaluated the vegetation effect on the surface albedo and ocean circulation during the late Miocene. We find that both effects contribute to a relatively warm late Miocene climate in the North Atlantic realm. Such warming has been reported from terrestrial proxy evidence (e.g., Wolfe, 1994, [66]). The albedo is strongly reduced through the presence of vegetation (greening) and through the vegetation-snow-albedo feedback (reduction of the snow-albedo feedback in the presence of vegetation). Several modeling studies found that paleovegetation-climate feedback may have significantly contributed to the Cenozoic climate evolution (Dutton and Barron, 1997, [30]; Knorr et al., 2011, [41]; Bradshaw et al., 2015, [67]). However, the possible synergy of vegetation and climate can vary with different background conditions. Bradshaw et al., (2015, [67]) suggest that climate sensitivity to $\mathrm{CO}_{2}$ forcing is directly affected by the palaeogeographic configuration and that the inferred climate sensitivity is higher for the late Miocene than we might expect for future climate because of the differences in vegetation distribution (e.g., tropical forest changes) in conjunction with differences in ocean circulation and sea ice. Most models indicate a weaker overturning rate of the deep ocean circulation during the Miocene (Herold et al., 2012, [68] and references therein) which is accompanied with reduced high-latitude salinities and lowered northern North Atlantic temperatures.

Associated with the changes in the atmospheric circulation, we detect enhanced water vapor export out of the Atlantic catchment area for the Tortonian in the presence of vegetation. The enhanced water vapor transport is caused by an increase in the zonal moisture transport associated with the Atlantic trade winds. Triggered by high salinities at northern high latitudes, North Atlantic Deep Water is formed and the sea ice edge is moved poleward, in general agreement with proxy data (e.g., Wolf and Thiede, 1991, [69]). A stabilizing effect of the ocean circulation has been proposed for tropical water vapor transport during glacials (Lohmann and Lorenz, 2000, [70]) which may be responsible for an additional sea surface salinity contrast between the Atlantic and Pacific/Indian Oceans (Broecker, 1992, [71]; Zaucker and Broecker, 1992, [72]; Zaucker et al., 1994, [73]), for times when the Atlantic overturning is weaker (Lohmann, 2003, [63]), as well as for El Niño conditions (Schmittner et al., 2000, [74]; Soden, 2000, [75]; Latif et al., 2000, [76]). As pointed out by Steppuhn et al., (2006, [33]), there is a significant warming of more than $2{ }^{\circ} \mathrm{C}$ at the eastern margin of the Pacific Ocean associated with a decreased upwelling in this area. This is linked to a weaker equatorial Walker circulation and a Tortonian permanent El-Niño state. Fedorov et al., (2006, [77]) proposed that a permanent El-Niño state might have contributed to the Pliocene glaciation and Cenozoic climate evolution. This aspect will be analyzed in a subsequent study using a fully coupled atmosphere-ocean circulation model for the late Miocene. In our experiments, we changed the wind stress and the hydrological cycle in our hybrid-coupled model approach. Sensitivity experiments indicate that the direct wind effect turns out to be of secondary importance in our simulations (not shown).

New proxy compilations (LaRiviere et al., 2012, [78]; Goldner et al., 2014, [79]; references therein) indicate a substantial increase of several degrees in SST. Our simulations suggest a pronounced warming in the northern North Atlantic and North Pacific Oceans and a moderate warming in the tropical Atlantic Ocean and some regions in the Southern Hemisphere. Compared to LaRiviere et al., (2012, [78]), the warming in the northern North Pacific Ocean is not as strong as in reconstructions. It has been speculated that other mechanisms such as a long-term trend of thermocline shoaling and feedbacks may have been 
responsible for the warmth of the late Miocene (LaRiviere et al., 2012, [78]). A detailed model-data comparison is however not our intension here. Goldner et al., (2014, [79]) illustrate that the Mid-Miocene climate optimum is difficult to be simulated by a state-of-the-art climate model with $\mathrm{CO}_{2}$ concentrations reconstructed for the Miocene, and concluded that either the models are not sensitive enough or that additional forcings remain missing to explain half of the anomalous warmth and pronounced polar amplification. In addition, it is possible that other mechanisms not included in the present generation of GCMs also might have had an important impact on Tortonian climate, such as high-latitude radiative warming by polar stratospheric clouds (Sloan and Pollard, 1998, [80]), increased ocean heat transport driven by tropical cyclone-induced mixing (e.g., Emanuel, 2002, [81]), or increased levels of greenhouse gases such as methane. Methane can be estimated through stable carbon isotopes (biological processes preferentially incorporate carbon-12) and areas of wetlands as calculated from the land surface scheme including the vegetation distribution.

In our approach we used a "one-way interaction" model. Sensitivity experiments using fully coupled models (i.e., two-way interaction between vegetation and ocean) would provide more comprehensive information on the interaction between vegetation and ocean circulation in the Late Miocene. Furthermore, we have to take into account that the uncertainty in the $\mathrm{CO}_{2}$ reconstructions is at least $150 \mathrm{ppm}$ (larger than the glacial-interglacial variations), therefore we are unable to state that the $\mathrm{CO}_{2}$ concentrations did not vary (cf. Kürschner et al., 2008, [39]; Zhang et al., 2013, [40]; and references therein). Therefore, fully interactive atmosphere-ocean-ice-biogeochemistry models might be necessary in order to examine the Earth system feedbacks for the Miocene.

To further investigate major developments during the Miocene, a combined approach between modeling and establishing proxy records from selected key locations is needed. Model results on changing patterns of heat transport can be validated by temperature reconstructions $(\mathrm{Mg} / \mathrm{Ca}$, alkenones, TEX86), both from the deep (benthic fauna) and the shallow (planktonic) ocean (Lear et al., 2003, [82]; Billups et al., 2002, [83]; Sluijs et al, 2006, [84]). Interestingly, the deep water in the North Atlantic Ocean indicates a warm signature during the late Miocene (Lear et al., 2003, [82]) which can be interpreted as an already established meridional overturning circulation at this time. Before and after the Tortonian North Atlantic temperatures were much lower and indicate a reduced ocean circulation. In a next step, we should test the extent to which temporal shifts in growing season or vertical shifts in depth habitat can reduce model-data and data-data misfits and uncertainties (cf. Lohmann et al., (2013, [85]) for a similar analysis of Holocene sea surface temperatures). Figure $10 \mathrm{~b}$ indicates large vertical temperature changes between the experiments which are interesting in terms of differing temperature reconstuctions. For example, some proxies might reflect subsurface signature more explicitely than the other proxies and they show a different equator-to-pole gradient. Similarly, a quantitative terrestrial model-data comparison for the late Miocene has been undertaken by Bradshaw et al., (2012, [86]), which incorporated a conservative estimate of uncertainties associated with both the model output and the data reconstructions.

Major changes in ocean circulation can be further traced by using water mass characteristic proxies like Cd/Ca, Nd isotopes, and carbon-13 (Frank et al., 1999, [87]; Frank et al., 2002, [88]; Delaney and Boyle, 1987, [89]; Butzin et al., 2011, [90]). The combination of temperature reconstructions with oxygen-18 gives evidence on changes in salinity and may provide indications on the high salinities in the northern North Atlantic and associated strong ocean circulation. 
It can be speculated that the overturning effect which is described here is relevant for other time slices as well. Zhang et al., (2013) [91] analyzed the models participating in Pliocene Modeling Intercomparison Project (PlioMIP) and showed that the simulated mid-Pliocene Atlantic northward heat transport is similar to the pre-industrial. The consistent change in Atlantic deep circulation is a moderate shoaling of the overturning cell in the Atlantic, but there might be also model-dependent factors like the Arctic Ocean sea surface salinity (Stepanek and Lohmann, 2012, [92]) which potentially stem from vegetation-ocean feedbacks for such climate states. Further studies are required to examine the possible feedbacks for such climate states, which might be crucial for the high-latitude climate during the Cenozoic.

\section{Conclusions}

The Cenozoic climate evolution includes significant changes in the oceanic transports which are ultimately linked to the paleotopography and opening and closing of passages. Our study aims at exploring the effect of land-cover changes as a non- $\mathrm{CO}_{2}$ forcing that might have happened during the late Miocene. When the CAS permitted exchange of fresh Pacific water with saline Atlantic water the density in the North Atlantic Ocean is reduced, thus affecting the large-scale ocean circulation. We find that a modified land surface cover can compensate this gateway effect showing an almost present oceanic northward heat transport. Essential for this mechanism is the increased interbasin fresh water transport in conjunction with a positive feedback of enhanced thermohaline-driven ocean circulation.

Our results indicate that the reorganization of vegetation zones, topographical changes and changes in the global ocean circulation could have played a dominant role in the major Cenozoic climate transitions. Consequently, it is of utmost importance not only to understand the behavior of these individual systems in better detail but also to investigate the full dynamics, feedbacks, and synergisms of the coupled system (including the carbon cycle). The high-latitude warming likely involves many different nonlinear feedbacks to the imposed changes (Lyle et al., 2008, [93]; Knorr et al., 2011, [41]; Knorr and Lohmann, 2014, [94]). Kürschner et al., (2008, [57]) point to a long-term coupling between atmospheric $\mathrm{CO}_{2}$ and climate, but indicate large fluctuations in greenhouse gas concentrations during the Miocene affecting the evolution of terrestrial ecosystems.

The Cenozoic is a proper test bed for large structural changes in a similar, but warmer climate with major regional heterogeneities. In the late Miocene, the reconstructed elevated global-mean surface temperatures and weaker equator-to-pole temperature gradients are underestimated in our model (as in all models which we are aware of). However, comparing proxy data with models, one should furthermore test the assumptions in the recorder systems (e.g., temporal shifts in recording season, shifts in depth habitat, recorder specific assumptions) by using proxy models and statistical analysis. As a logical next step, we will apply such tools to examine the large-scale temperature gradients under external forcings during the Miocene.

\section{Acknowledgments}

Arne Micheels and Volker Mosbrugger are acknowledged for discussions on an earlier manuscript and for providing some of the forcing data. Thanks go to Stefanie Klebe for proofreading. Silke Schubert and Marco Scholze are acknowledeged for help in performing the LPJ runs, and Andreas Manschke is acknowledged for help in model data processing. The work has been supported by the Helmholtz 
programme PACES, the DFG research group UCCC, and the excellence cluster marum. The authors thank three anonymous referees for their constructive comments.

\section{Author Contributions}

GL designed the study and wrote the manuscript with significant contributions of MB and TB. MB conducted the ocean model simulations. All authors contributed to interpretation and the preparation of the final manuscript.

\section{Conflicts of Interest}

The authors declare no conflict of interest.

\section{References}

1. Zachos, J.; Pagani, M.; Sloan, L.; Thomas, E.; Billups, K. Trends, rhythms, and aberations in global climate 65 Ma to Present. Science 2001, 29, 686-693.

2. DeConto, R.M.; Pollard, D. Rapid Cenozoic glaciation of Antarctica induced by declining atmospheric CO2. Nature 2003, 421, 245-249.

3. Kennett, J.P. Cenozoic evolution of Antarctic glaciation, the Circum Antarctic Ocean, and their impact on global paleoceanography. J. Geophys. Res. 1977, 82, 3843-3860.

4. Wright, J.D.; Miller, K.G. Control of North Atlantic Deep Water circulation by the Greenland-Scotland Ridge. Paleoceanography 1996, 11, 157-169.

5. Billups, K. Late Miocene through early Pliocene deep water circulation and climate change viewed from the sub-Antarctic South Atlantic. Palaeogeogr. Palaeoclimatol. Palaeoecol. 2002, 185, 287-307.

6. Cane, M.A.; Molnar, P. Closing of the Indonesian seaway as a precursor to east African aridification around 3-4 million years ago. Nature 2001, 411, 157-161.

7. Lawver, L.A.; Gahagan, L.M. Evolution of Cenozoic seaways in the circum-Antarctic region. Palaeogeogr. Palaeoclimatol. Palaeoecol. 2003, 198, 11-37.

8. Flower, B.P.; Kennett, J.P. The middle Miocene climatic transition: East Antarctic ice sheet development, deep ocean circulation and global carbon cycling. Palaeogeogr. Palaeoclimatol. Palaeoecol. 1994, 108, 537-555.

9. Haug, G.; Tiedemann, R. Effect of the formation of the Isthmus of Panama on Atlantic Ocean thermohaline circulation. Nature 1998, 393, 673-676.

10. Mudelsee, M.; Bickert, T.; Lear, C.H.; Lohmann, G. Cenozoic climate changes: A review based on time series analysis of marine benthic $\delta 18 \mathrm{O}$ records. Rev. Geophys. 2014, 52, 1-42.

11. Greenwood, D.R.; Wing, S.L. Eocene continental climates and latitudinal temperature gradients. Geology 1995, 23, 1044-1048.

12. Crowley, T.J.; Zachos, J.C. Comparison of zonal temperature profiles for past warm periods. In Warm Climates in Earth History; Huber, B., MacLeod, K.G., Wing, S.C., Eds.; Cambridge University Press: New York, NY, USA, 2000; pp. 50-76. 
13. Pound, M.; Haywood, A.M.; Salzman, U.; Riding, J.B. Global vegetation dynamics and latitudinal temperature gradients during the Mid to LateMiocene (15.97-5.33 Ma). Earth Sci. Rev. 2012, 112, $1-22$.

14. Barron, E.J. Eocene equator-to-pole surface ocean temperature: A significant climate problem? Paleoceanography 1987, 2, 729-739.

15. Huber, M.; Sloan, L. Heat transport, deep waters and thermal gradients: Coupled climate simulation of an Eocene greenhouse climate. Geophys. Res. Lett. 2001, 28, 3481-3484.

16. Micheels, A.; Bruch, A.A.; Eronen, J.; Fortelius, M.; Harzhauser, M.; Utescher, T.; Mosbrugger, V. Analysis of heat transport mechanisms from a late Miocene model experiment with a fully-coupled atmosphere-ocean general circulation model. Palaeogeogr. Palaeoclimatol. Palaeoecol. 2011, 304, 337-350.

17. Schmidt, G.A.; Mysak, L.A. Can increased poleward oceanic heat flux explain the warm Cretaceous climate? Paleoceanography 1996, 11, 579-593.

18. Hay, W.W.; DeConto, R.M.; Wold, C.N. Climate: Is the past key to the future? Geol. Rundsch. 1997, 86, 471-491.

19. Caballero, R.; Langen, P. The dynamic range of poleward energy transport in an atmospheric general circulation model. Geophys. Res. Lett. 2005, 32, doi:10.1029/2004GL021581.

20. Wright, J.D.; Miller, K.G.; Fairbanks, R.G. Miocene stable isotopes: Implications for deepwater circulation and climate. Paleoceanography 1992, 7, 357-389.

21. Montes, C.; Cardona, A.; Jaramillo, C.; Pardo, A.; Silva, J.C.; Valencia, V.; Pérez-Angel, L.C.; Ayala, C.; Rodriguez-Parra, L.A.; Ramirez, V.; et al. Middle Miocene closure of the Central American Seaway. Science 2015, 348, 226-229.

22. Mikolajewicz, U.; Maier-Reimer, E.; Crowley, T.J.; Kim, K.J. Effect of Drake and Panamanian gateways on the circulation of an ocean model. Paleoceanography 1993, 8, 409-426.

23. Bice, K.L.; Scotese, C.R.; Seidov, D.; Barron, E.J. Quantifying the role of geographic change in Cenozoic ocean heat transport using uncoupled atmosphere and ocean models. Palaeogeogr. Palaeoclimatol. Palaeoecol. 2000, 161, 295-310.

24. Retallack, G. Cenozoic expansion of grasslands and climatic cooling. J. Geol. 2001, 109, 407-426.

25. Willis, K.J.; McElwain, J.C. The Evolution of Plants; Oxford University Press: Oxford, UK, 2002; p. 378.

26. Morley, R.J. Origin and Evolution of Tropical Rain Forests; Wiley: Chichester, UK, 2000; p. 362.

27. Bredenkamp, G.J.; Spada, F.; Kazmieczak, E. On the origin of northern and southern hemisphere grasslands. Plant Ecol. 2002, 163, 209-229.

28. Cerling, T.E.; Harris, J.M.; MacFadden, B.J.; Leakey, M.G.; Quade, J.; Eisenmann, V.; Ehleringer, J.R. Global vegetation change through the Miocene/Pliocene boundary. Nature 1997, 389, 153-159.

29. Freeman, K.H.; Colarusso, L.A. Molecular and isotopic records of C4 grassland expansion in the late Miocene. Geochim. Cosmochim. Acta 2001, 65, 1439-1454.

30. Dutton, J.F.; Barron, E.J. Miocene to present vegetation changes: A possible piece of the Cenozoic puzzle. Geology 1997, 25, 39-41.

31. Otto-Bliesner, B.; Upchurch, G.R. Vegetation-induced warming of high-latitude regions during the Late Cretaceous period. Nature 1997, 385, 804-807. 
32. Roeckner, E.; Arpe, K.; Bengtsson, L.; Christoph, M.; Claussen, M.; Dümenil, L.; Esch, M.; Giorgetta, M.; Schlese, U.; Schulzweida, U. The Atmospheric General Circulation Model ECHAM-4: Model Description and Simulation of Present-Day Climate, Max-Planck-Institut für Meteorologie; MPI Report No. 218; Max-Planck-Institute: Hamburg, Germany, 1996.

33. Steppuhn, A.; Micheels, A.; Geiger, G.; Mosbrugger, V. Reconstructing the Late Miocene Climate and oceanic heat flux using the AGCM ECHAM4 coupled to a mixed-layer ocean model with adjusted flux correction, Palaeogeogr. Palaeoclimatol. Palaeoecol. 2006, 238, 399-423.

34. Freeman, H.H.; Hayes, J.M. Fractionation of carbon isotopes by phytoplankton and estimates of ancient CO2 levels. Global Biogeochem. Cycles 1992, 6, 185-198.

35. Pagani, M.; Arthur, M.A.; Freeman, K.H. Miocene evolution of atmospheric carbon dioxide. Paleoceanography 1999, 14, 273-292.

36. Pearson, P.N.; Palmer, M.R. Atmospheric carbon dioxide concentrations over the past 600 million years. Nature 2000, 406, 695-699.

37. Demicco, R.V.; Lowenstein, T.K.; Hardie, L.A. Atmospheric pCO2 since 60 Ma from records of seawater $\mathrm{pH}$, calcium and primary carbonate mineralogy. Geology 2003, 31, 793-796.

38. Pagani, M.; Zachos, J.C.; Freeman, K.H.; Tipple, B.; Bohaty, S. Marked decline in atmospheric carbon dioxide concentrations during the Paleogene. Science 2005, 309, 600-603.

39. Kürschner, W.M.; Kvaček, Z.; Dilcher, D.L. The impact of Miocene atmospheric carbon dioxide fluctuations on climate and the evolution of terrestrial ecosystems. PNAS 2008, 105, 449-453.

40. Zhang, Y.G.; Pagani, M.; Liu, Z.; Bohaty, S.M.; Deconto, R. A 40-million-year history of atmospheric $\mathrm{CO}_{2}$. Philos. Trans. A Math. Phys. Eng. Sci. 2013, 371, doi: 10.1098/rsta.2013.0096.

41. Knorr, G.; Butzin, M.; Micheels, A.; Lohmann, G. A Warm Miocene Climate at Low Atmospheric CO2 levels. Geophys. Res. Lett. 2011, doi:10.1029/2011GL048873.

42. New, M.; Hulme, M.; Jones, P. Representing Twentieth-Century Space-Time Climate Variability. Part I: Development of a 1961-90 Mean Monthly Terrestrial Climatology. J. Climate 1999, 12, 829-856.

43. Micheels, A. Late Miocene climate modelling with ECHAM4/ML-The effects of the palaeovegetation on the Tortonian climate. Ph.D. Thesis, University of Tübingen, Tübingen, Germany, 2003; p. 110.

44. Micheels, A.; Bruch, A.A.; Uhl, D.; Utescher, T.; Mosbrugger, V. A Late Miocene climate model simulation with ECHAM4/ML and its quantitative validation with terrestrial proxy data. Palaeogeogr. Palaeoclimatol. Palaeoecol. 2007, 253, 251-270.

45. Pickford, M. Crocodiles from the Beglia Formation, Middle/Late Miocene Boundary, Tunisia, and their significance for Saharan palaeoclimatology. Ann. Paleontol. 2000, 86, 59-67.

46. Micheels, A.; Eronen, J.; Mosbrugger, V. The Late Miocene climate response to a modern Sahara desert. Global Planet. Chang. 2009, 67, 193-204.

47. Vignaud, P.; Duringer, P.; Mackaye, H.T.; Likius, A.; Blondel, C.; Boisserie, J.-R.; de Bonis, L.; Eisenmann, V.; Etienne, M.E.; Geraads, D.; et al. Geology and paleontology of the Upper Miocene Toros-Menalla hominidlocality, Chad. Nature 2002, 418, 152-155.

48. Wolfe, J.A. Distribution of major vegetational types during the Tertiary. In The Carbon Cycle and Atmospheric $\mathrm{CO}_{2}$ Natural Variations Archean to Present; Sundquist, E.T., Broecker, W.S., Eds.; American Geophysical Union: Washington, DC, USA, 1985; pp. 357-375. 
49. Sitch, S.; Smith, B.; Prentice, I.C.; Arneth, A.; Bondeau, A.; Cramer, W.; Kaplan, J.O.; Levis, S.; Lucht, W.; Sykes, M.T.; et al. Evaluation of ecosystem dynamics, plant geography and terrestrial carbon cycling in the LPJ dynamic global vegetation model. Global Chang. Biol. 2003, 9, 161-185.

50. Kaplan, J.O.; Prentice, I.C.; Knorr, W.; Valdes, P.J. Modelling the dynamics of terrestrial carbon storage since the Last Glacial Maximum. Geophys. Res. Lett. 2002, 29, 2074-2078.

51. Scholze, M.; Knorr, W.; Heimann, M. Modelling terrestrial vegetation dynamics and carbon cycling for an abrupt climate change event. Holocene 2003, 13, 327-333.

52. Maier-Reimer, E.; Mikolajewicz, U.; Hasselmann, K. Mean circulation of the Hamburg LSG OGCM and its sensitivity to the thermohaline surface forcing. J. Phys. Oceanogr. 1993, 23, 731-757.

53. Schäfer-Neth, C.; Paul, A. Circulation of the glacial Atlantic: A synthesis of global and regional modeling. In The northern North Atlantic: A changing environment; Schäfer, P., Ritzrau, W., Schlüter, M., Thiede, J., Eds.; Springer: Berlin, Germany, 2001; pp. 446-462.

54. Prange, M.; Romanova, V.; Lohmann, G. The glacial thermohaline circulation: Stable or unstable? Geophys. Res. Lett. 2002, 29, doi:10.1029/2002GL015337.

55. Prange, M.; Lohmann, G.; Paul, A. Influence of vertical mixing on the thermohaline hysteresis: Analyses of an OGCM. J. Phys. Oceanogr. 2003, 33, 1707-1721.

56. Lohmann, G. The influence of a near-bottom transport parameterization on the sensitivity of the thermohaline circulation. J. Phys. Oceanogr. 1998, 28, 2095-2103.

57. Lohmann, G.; Schulz, M. Reconciling Bølling warmth with peak deglacial meltwater discharge. Paleoceanography 2000, 15, 537-540.

58. Butzin, M.; Prange, M.; Lohmann, G. Radiocarbon simulations for the glacial ocean: The effects of wind stress, Southern Ocean sea ice and Heinrich events. Earth Planet. Sci. Lett. 2005, 235, 45-61.

59. Lohmann, G.; Gerdes, R. Sea ice effects on the sensitivity of the thermohaline circulation in simplified atmosphere-ocean-sea ice models. J. Clim. 1998, 11, 2789-2803.

60. Knorr, G.; Lohmann, G. Southern Ocean origin for resumption of Atlantic thermohaline circulation during deglaciation. Nature 2003, 424, 532-536.

61. Boulter, M.C.; Manum, S.B. A lost continent in temperate Arctic. Endevour 1997, 21, 105-108.

62. Schuster, M.; Duringer, P.; Ghienne, J.-F.; Vignaud, P.; Mackaye, H.T.; Likius, A.; Brunet, M. The Age of the Sahara Desert. Science 2006, 311, doi:10.1126/science.1120161.

63. Lohmann, G. Atmospheric and oceanic freshwater transport during weak Atlantic overturning circulation. Tellus A 2003, 55, 438-449.

64. Schmitz, W.J. On the interbasin scale thermohaline circulation. Rev. Geophys. 1995, 33, 151-173.

65. Macdonald, A.M.; Wunsch, C. An estimate of global ocean circulation and heat fluxes. Nature 1996, 382, 436-439.

66. Wolfe, J.A. An analysis of Neogene climates in Beringia. Palaeogeogr. Palaeoclimatol. Palaeoecol. 1994, 108, 207-216.

67. Bradshaw, C.D.; Lunt, D.J.; Flecker, R.; Davies-Barnard, T. Disentangling the roles of late Miocene palaeogeography and vegetation-Implications for climate sensitivity. Palaeogeogr. Palaeoclimatol. Palaeoecol. 2015, 417, 17-34.

68. Herold, N.; Huber, M.; Müller, R.D.; Seton, M. Modeling the Miocene climatic optimum: Ocean circulation. Paleoceanography 2012, 27, doi:10.1029/2010PA002041. 
69. Wolf, T.C.W.; Thiede, J. History of terrigenous sedimentation during the past 10 m.y. in the North Atlantic (ODP Legs 104 and 105 and DSDP Leg 81). Mar. Geol. 1991, 101, 83-102.

70. Lohmann, G.; Lorenz, S. On the hydrological cycle under paleoclimatic conditions as derived from AGCM simulations. J. Geophys. Res. 2000, 105, 417-436.

71. Broecker, W.S. The salinity contrast between the Atlantic and Pacific during glacial time. Paleoceanography 1992, 4, 207-212.

72. Zaucker, F.; Broecker, W.S. The influence of atmospheric moisture transport on fresh water balance of the Atlantic drainage basin: General circulation model simulations and observations. J. Geophys. Res. 1992, 97, 2765-2773.

73. Zaucker, F.; Stocker, T.F.; Broecker, W.S. Atmospheric freshwater fluxes and their effect on the global thermohaline circulation. J. Geophys. Res. 1994, 99, 12443-12457.

74. Schmittner A.; Appenzeller, C.; Stocker, T.F. Enhanced Atlantic freshwater export during El Niño. Geophys. Res. Lett. 2000, 27, 1163-1166.

75. Soden, B.J. The sensitivity of the tropical hydrological cycle to ENSO. J. Clim. 2000, 13, 538-549.

76. Latif, M.; Roeckner, E.; Mikolajewicz, U.; Voss, R. Tropical stabilization of the thermohaline circulation in a greenhouse warming simulation. J. Clim. 2000, 13, 1809-1813.

77. Fedorov, V.; Dekens, P.S.; McCarthy, M.; Ravelo, A.C.; deMenocal, P.B.; Barreiro, M.; Pacanowski, R.C.; Philander, S.G. The Pliocene paradox (Mechanisms for a permanent El Niño). Science 2006, 312, 1485-1489.

78. LaRiviere, J.P.; Ravelo, A.C.; Crimmins, A.; Dekens, P.S.; Ford, H.L.; Lyle, M.; Wara, M.W. Late Miocene decoupling of oceanic warmth and atmospheric carbon dioxide forcing. Nature 2012, 486, 97-100.

79. Goldner, A.; Herold, N.; Huber, M. The challenge of simulating the warmth of the mid-Miocene climatic optimum in CESM1. Clim. Past 2014, 10, 523-536.

80. Sloan, L.C.; Pollard, D. Polar stratospheric clouds: A high latitude warming mechanism in an ancient greenhouse world. Geophys. Res. Lett. 1998, 25, 3517-3520.

81. Emanuel, K. A simple model for multiple climate regimes. J. Geophys. Res. 2002, 107, doi:10.1029/2001/JD001002.

82. Lear, C.H.; Rosenthal, Y.; Wright, J.D. The closing of a seaway: Ocean water masses and global climate change. Earth Planet. Sci. Lett. 2003, 210, 425-436.

83. Billups, K.; Channell, J.E.T.; Zachos, J. Late Oligocene to early Miocene geochronology and paleoceanography. Paleoceanography 2002, 17, doi:10.1029/2000PA000568.

84. Sluijs, A.; Schouten, S.; Pagani, M.; Woltering, M.; Brinkhuis, H.; Sinninghe Damste, J.S.; Dickens, G.R.; Huber, M.; Reichart, G.-J.; Stein, R.; et al. Subtropical Arctic Ocean temperatures during the Palaeocene/Eocene thermal maximum. Science 2006, 441, 610-613.

85. Lohmann, G.; Pfeiffer, M.; Laepple, T.; Leduc, G.; Kim, J.-H. A model-data comparison of the Holocene global sea surface temperature evolution. Clim. Past 2013, 9, 1807-1839.

86. Bradshaw, C.D.; Lunt, D.J.; Flecker, R.; Salzmann, U.; Pound, M.J.; Haywood, A.M.; Eronen, J.T. The relative roles of $\mathrm{CO} 2$ and palaeogeography in determining late Miocene climate: Results from a terrestrial model-data comparison. Clim. Past 2012, 8, 1257-1285. 
87. Frank, M.; O’Nions, R.K.; Hein, J.R.; Banakar, V.K. 60 Ma records of major elements and Pb-Nd isotopes from hydrogenous ferromanganese crusts: Reconstruction of seawater paleochemistry. Geochim. Cosmochim. Acta 1999, 63, 1689-1708.

88. Frank, M.; Whiteley, N.; Kasten, S.; Hein, J.R.; O’Nions, R.K. North Atlantic Deep Water export to the Southern Ocean over the past $14 \mathrm{Myr}$ : Evidence from $\mathrm{Nd}$ and $\mathrm{Pb}$ isotopes in ferromanganese crusts. Paleoceanography 2002, 17, doi:10.1029/2000PA000606.

89. Delaney, M.; Boyle, E.A. Cd/Ca in Late Miocene benthic foraminifera and changes in the global organic carbon budget. Nature 1987, 330, 156-159.

90. Butzin, M.; Lohmann, G.; Bickert, T. Miocene ocean circulation inferred from marine carbon cycle modeling combined with benthic isotope records. Paleoceanography 2011, 26, doi:10.1029/2009PA001901.

91. Zhang, Z.-S.; Nisancioglu, K.H.; Chandler, M.A.; Haywood, A.M.; Otto-Bliesner, B.L.; Ramstein, G.; Stepanek, C.; Abe-Ouchi, A.; Chan, W.-L.; Bragg, F.J.; et al. Mid-Pliocene Atlantic Meridional Overturning Circulation not unlike modern? Clim. Past 2013, 9, 1495-1504.

92. Stepanek, C.; Lohmann, G. Modelling mid-Pliocene climate with COSMOS. Geosci. Model Dev. 2012, 5, 1221-1243.

93. Lyle, M.; Barron, J.; Bralower J.; Huber, M., Lyle, A.O.; Ravelo, A.C.; Rea, R.K.; Wilson, P. Pacific Ocean and cenozoic evolution of climate. Rev. Geophys. 2008, 46, doi:10.1029/2005RG000190.

94. Knorr, G.; Lohmann, G. A warming climate during the Antarctic ice sheet growth at the Middle Miocene transition. Nat. Geosci. 2014, 7, 376-381.

(C) 2015 by the authors; licensee MDPI, Basel, Switzerland. This article is an open access article distributed under the terms and conditions of the Creative Commons Attribution license (http://creativecommons.org/licenses/by/4.0/). 